\title{
Alpha radiolysis of DOTA ligand in aqueous solutions with helium ion beams
}

Vincent Fiegel $^{\mathrm{a}}$, Claude Berthon ${ }^{\mathrm{a}}$, Amaury Costagliola ${ }^{\mathrm{c}}$, Guillaume Blain ${ }^{\mathrm{c}}$, Johan Vandenborre ${ }^{\mathrm{c}}$, Jackie Vermeulen $^{\mathrm{a}}$, Georges Saint-Louis ${ }^{\mathrm{a}}$, Laetitia Guerinn, Thierry Sauvage ${ }^{\mathrm{b}}$, Massoud FattahiVananic $^{c}$, Laurent Venault ${ }^{\mathrm{a}}$, Laurence Berthon ${ }^{\mathrm{a}^{*}}$.

${ }^{a}$ CEA, DEN, MAR, DMRC, F-30207 Bagnols-sur-Cèze, France

${ }^{\mathrm{b}}$ CEMHTI Site Cyclotron, CNRS, 3A rue de la Férollerie, 45071 Orléans Cedex 2, France

c SUBATECH, UMR 6457, Institut Mines-Télécom Atlantique, CNRS/IN2P3, Université de Nantes, 4 rue Alfred Kastler, La Chantrerie BP 20722, 44307 Nantes Cedex 3, France

* Corresponding author: laurence.berthon@ cea.fr

\section{HIGHLIGHTS}

- Alpha irradiation of DOTA ligand in pure water with helium ion beam was studied.

- As DOTA concentration in water increases, $\mathrm{H}_{2} \mathrm{O}_{2}$ formation decreases.

- Whereas molecular hydrogen $\left(\mathrm{H}_{2}\right)$ and carbon dioxide $\left(\mathrm{CO}_{2}\right)$ formation increases.

- DOTA degradation products were identified by ESI-MS.

- A degradation scheme for the DOTA ligand is proposed.

\begin{abstract}
Samples of DOTA (1,4,7,10-tetraazacyclodécanetetraacetic acid) ligand in aqueous solutions have been irradiated with helium ion $\left({ }^{4} \mathrm{He}^{2+}\right)$ beams of the ARRONAX (Nantes) and CEMHTI (Orléans) cyclotrons. Formation yields of gaseous radiolysis products $\left(\mathrm{H}_{2}, \mathrm{CO}_{2} \ldots\right)$ have been measured by micro-gas chromatography. Yield of hydrogen peroxide has in turn been determined by colorimetric titration with titanium (IV). Degraded solutions were also analyzed by electrospray ionization mass spectrometry (ESI-MS) and nuclear magnetic resonance spectroscopy (NMR) in order to identify degradation products formed after irradiation and quantify the non-degraded DOTA ligand. Results showed that the presence of DOTA in water leads to an increase of $\mathrm{G}\left(\mathrm{H}_{2}\right)$ and a decrease of $\mathrm{G}\left(\mathrm{H}_{2} \mathrm{O}_{2}\right)$. A degradation scheme is proposed: DOTA is degraded through decarboxylation, losing $\mathrm{CO}_{2}$ moieties, condensation of two carboxylic acid moieties with elimination of either a carbonic acid or a glycolic acid group, cleavage of $-\mathrm{CH}_{2}-\mathrm{COOH}, \mathrm{N}-\mathrm{CH}_{2}-\mathrm{COOH}$ and $\left(\mathrm{CH}_{2}-\mathrm{CH}_{2}\right) \mathrm{N}-\mathrm{CH}_{2}-\mathrm{COOH}$ fragments, or by recombination with a hydroxyl radical $\left({ }^{\circ} \mathrm{OH}\right)$. NMR analyses showed that almost a third of DOTA ligand was degraded after $110 \mathrm{kGy}$ alpha irradiation dose.
\end{abstract}

Keywords: DOTA, alpha radiolysis, helium ion beam, cyclotron, ESI-MS, degradation products.

\section{Introduction}

The polyaminocarboxylic acids have the ability to form very stable complexes with most metal ions (Gritmon et al., 1977; Clarke \& Martell, 1991; Chaves et al., 1992; Byegård et al., 1999; Choppin et al., 2006) making these ligands widely used in the nuclear and medical fields. 
In the nuclear field, DTPA (diethylenetriaminepentaacetic acid) is mainly used for decorporation of actinides after accidental contamination of workers (Fried \& Schubert, 1961; Poudel et al., 2017; Ansoborlo et al., 2007). These molecules have also been widely studied in the past decades as complexing agents for the potential recycling of minor actinides (americium and curium), which are the principal contributors to the long-term radiotoxicity and heat load of the nuclear waste and developed in different processes (Poinssot et al., 2012; Nilsson \& Nash, 2009; Nash, 2015; Braley et al., 2012; Lumetta et al., 2014; Vanel et al., 2012, 2016). In medical diagnostics, molecular imaging techniques use metals that are usually labelled with ligands to form highly stable complexes and reduce their toxicity or avoid biological accumulation (Hamplová et al., 2010). In this way, Gd-DOTA (gadoterate meglumine, DOTAREM®) is used as an MRI contrast agent for imaging body tissues or organs (Ishiguchi \& Takahashi, 2010), and ${ }^{68} \mathrm{Ga}$-DOTAconjugated peptides like [DOTA ${ }^{0}, \mathrm{Tyr}^{3}$ ]octreotide (DOTATOC) and [DOTA ${ }^{0}, \mathrm{Tyr}^{3}$ ]octreo-tate (DOTA-tate) are employed for imaging tumors via PET scans (Breeman et al., 2005). In cancer therapy, DOTA-conjugated peptides can also be labelled to many different $\beta$-emitter radionuclides such as ${ }^{131} \mathrm{I},{ }^{68} \mathrm{Ga},{ }^{90} \mathrm{Y},{ }^{111} \mathrm{In}$ and ${ }^{177} \mathrm{Lu}$ for treatment of neuroendocrine tumors (Goldenberg, 2002; Breeman et al., 2003; Reubi \& Maecke, 2008) or $\alpha$-emitter such as ${ }^{211} \mathrm{At}$, ${ }^{212} \mathrm{Bi},{ }^{213} \mathrm{Bi}$ and ${ }^{225} \mathrm{Ac}$ for metastatic or circulating tumors (Ferrier et al., 2019). In all these applications, EDTA, DTPA or DOTA are in close contact with radioactive metals, leading to radiolysis phenomena of these ligands. It is then necessary to study their behavior under irradiation. The DOTA ligand (1,4,7,10-tetraazacyclododecane-tetraacetic acid, noted $\mathrm{H}_{4} \mathrm{~L}$ in its neutral form, see Fig. 1) is here proposed as a model ligand of the polyaminocarboxylic acid molecules.

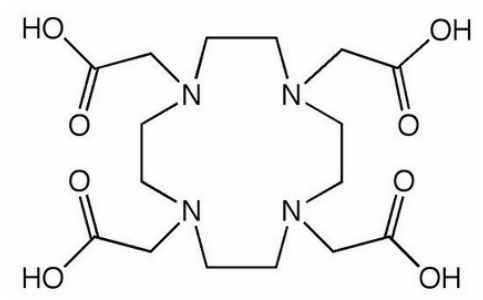

Fig. 1 : Semi-developed formula of the DOTA molecule (noted $\mathrm{H}_{4} \mathrm{~L}$ ).

In aqueous solutions, organic ligands such as DOTA can react with the radicals produced by radiolysis of water (Spinks \& Woods, 1990). Indeed, under irradiation, $\mathrm{H}_{2} \mathrm{O}$ molecules undergo ionization/excitation phenomena leading to the formation of free radicals that recombine to create different molecular species (Eq (1)) (Barr \& Allen, 1959; Spinks \& Woods, 1990). Among them, molecular hydrogen and hydrogen peroxide are the most stable species and are mainly formed according to the following reactions (Eqs (2) to (6)) (Buxton et al., 1988; Nagaishi \& Kumagai, 2011).

$$
\begin{array}{lr}
\mathrm{H}_{2} \mathrm{O} \sim \mathrm{e}_{\mathrm{aq}}^{-},{ }^{\mathrm{H}},{ }^{\circ} \mathrm{OH}, \mathrm{H}^{+}, \mathrm{OH}^{-}, \mathrm{H}_{2}, \mathrm{H}_{2} \mathrm{O}_{2} & \\
\cdot \mathrm{H}+{ }^{\cdot} \mathrm{H} \rightarrow \mathrm{H}_{2} & \mathrm{k}=7.8 \times 10^{9} \mathrm{~L} \mathrm{~mol}^{-1} \mathrm{~s}^{-1} \\
\mathrm{e}_{\mathrm{aq}}^{-}+{ }^{\cdot} \mathrm{H}+\mathrm{H}_{2} \mathrm{O} \rightarrow \mathrm{H}_{2}+\mathrm{OH}^{-} & \mathrm{k}=2.5 \times 10^{10} \mathrm{~L} \mathrm{~mol}^{-1} \mathrm{~s}^{-1}
\end{array}
$$




$$
\begin{aligned}
& \mathrm{e}_{\mathrm{aq}}^{-}+\mathrm{e}_{\mathrm{aq}}^{-}+2 \mathrm{H}_{2} \mathrm{O} \rightarrow \mathrm{H}_{2}+2 \mathrm{OH}^{-} \quad \mathrm{k}=5.5 \times 10^{9} \mathrm{~L} \mathrm{~mol}^{-1} \mathrm{~s}^{-1} \\
& \cdot \mathrm{OH}+{ }^{\circ} \mathrm{OH} \rightarrow \mathrm{H}_{2} \mathrm{O}_{2} \quad \mathrm{k}=5.5 \times 10^{9} \mathrm{~L} \mathrm{~mol}^{-1} \mathrm{~s}^{-1} \\
& \mathrm{e}^{-}{ }_{\mathrm{aq}}+{ }^{\cdot} \mathrm{OH} \rightarrow \mathrm{OH}^{-} \quad \mathrm{k}=3.0 \times 10^{10} \mathrm{~L} \mathrm{~mol}^{-1} \mathrm{~s}^{-1}
\end{aligned}
$$

The accumulation of these radicals and molecular species are affected by the linear energy transfer (LET) of heavy ion particles. The LET corresponds to the amount of energy deposited by the particle per unit of distance in a medium and is usually expressed in $\mathrm{keV}$ per $\mu \mathrm{m}^{-1}$. Increasing the particle LET increases the energy deposition density within the track of the heavy ion in the solution, increases the concentration of radicals, and therefore also increases the probability of radical-radical recombination reactions, producing a higher concentration of molecular species in solution (LaVerne, 1996). Moreover, the presence of organic solutes like DOTA in aqueous solution can also affect the production of these radicals, and in consequence, the formation of $\mathrm{H}_{2}$ or $\mathrm{H}_{2} \mathrm{O}_{2}$. Many organic compounds, like tert-butanol or methanol, are known to be very good scavengers of ${ }^{\circ} \mathrm{OH}$, decreasing the $\mathrm{H}_{2} \mathrm{O}_{2}$ formation yield by water radiolysis (Wojnárovits et al., 2004; Pastina \& LaVerne, 1999). Although there are no studies available on DOTA radiolysis, some works have reported the impact of ionizing radiation on polyaminocarboxylic acid molecules such as EDTA, HEDTA, DTPA or NTA (Bhattacharyya \& Srisankar, 1976; Bibler, 1972; Höbel \& von Sonntag, 1998; Toste, 1998; Zarzana et al., 2015). In the presence of ionizing radiation, these ligands are susceptible to be attacked in water by reactive species like ${ }^{\circ} \mathrm{H}$ and ${ }^{\circ} \mathrm{OH}$ radicals through hydrogen abstraction. These reactions can occur in the $\alpha$-position of a nitrogen atom of the molecules, as described in Eqs (7) and (8), leading to the formation of carboncentered radicals (Bhattacharyya \& Kundu, 1972; Höbel \& von Sonntag, 1998).

$$
\begin{aligned}
& \mathrm{RR}^{\prime} \mathrm{N}-\mathrm{CH}_{2}-\mathrm{COOH}+{ }^{\circ} \mathrm{H} \text { or }{ }^{\bullet} \mathrm{OH} \rightarrow \mathrm{RR}{ }^{\prime} \mathrm{N}-{ }^{\bullet} \mathrm{CH}-\mathrm{COOH}+\mathrm{H}_{2} \text { or } \mathrm{H}_{2} \mathrm{O} \\
& \mathrm{RR}^{\prime} \mathrm{N}-\mathrm{CH}_{2}-\mathrm{CH}_{2}-\mathrm{NRR}^{\prime}+{ }^{\circ} \mathrm{H} \text { or }{ }^{\bullet} \mathrm{OH} \rightarrow \mathrm{RR}^{\prime} \mathrm{N}-\mathrm{CH}_{2} \cdot{ }^{\bullet} \mathrm{CH}-\mathrm{NRR}^{\prime}+\mathrm{H}_{2} \text { or } \mathrm{H}_{2} \mathrm{O}
\end{aligned}
$$

In presence of oxygen, the dehydrogenated radical intermediate of $\mathrm{Eq}$ (7) may then react with $\mathrm{O}_{2}$ inducing the formation of a peroxide radical intermediate (Eq (9)), followed by the loss of a superperoxide ion, $\mathrm{O}_{2}{ }^{*-}$, and the formation of a tertiary iminium Schiff-base. It undergoes direct hydrolysis, leaving a secondary amine (RR'NH), and forms carbonyl products such as glyoxylic acid $(\mathrm{CHOCOOH})(\mathrm{Eq}(10))$ or formaldehyde $\left(\mathrm{CH}_{2} \mathrm{O}\right)$ and $\mathrm{CO}_{2}$ (Eq (11)) (Bhattacharyya \& Srisankar, 1976). In addition to the loss of $-\mathrm{CH}_{2} \mathrm{COOH}$ fragments, polyaminocarboxylic acids can undergo cleavage of larger, nitrogen-containing fragments, such as $-\mathrm{NCH}_{2} \mathrm{COOH}$, as well as or just $\mathrm{CO}_{2}$ moieties (Zarzana et al., 2015).

$$
\begin{aligned}
& \mathrm{RR}{ }^{\prime} \mathrm{N}-{ }^{\circ} \mathrm{CH}-\mathrm{COOH}+\mathrm{O}_{2} \rightarrow \mathrm{RR}{ }^{\prime} \mathrm{N}-\mathrm{CH}\left({ }^{\circ} \mathrm{O}_{2}\right)-\mathrm{COOH} \\
& \mathrm{RR}^{\prime} \mathrm{N}-\mathrm{CH}\left({ }^{\circ} \mathrm{O}_{2}\right)-\mathrm{COOH}+\mathrm{H}_{2} \mathrm{O} \rightarrow \mathrm{RR}^{\prime} \mathrm{NH}+\mathrm{CHOCOOH}+\mathrm{HO}_{2}{ }^{\circ} \\
& \mathrm{RR}^{\prime} \mathrm{N}-\mathrm{CH}\left({ }^{\circ} \mathrm{O}_{2}\right)-\mathrm{COOH}+\mathrm{H}_{2} \mathrm{O} \rightarrow \mathrm{RR}^{\prime} \mathrm{NH}+\mathrm{CH}_{2} \mathrm{O}+\mathrm{CO}_{2}+\mathrm{HO}_{2}{ }^{\circ}
\end{aligned}
$$


The goal of this work is to study the radiolytic stability of DOTA in aqueous solutions under external alpha irradiation. Helium ion beams will be used in order to simulate the effect of the ionizing radiation coming from radio-isotopes, making the handling of the solution easier. First, the influence of the presence of the DOTA ligand on the production yields of $\mathrm{H}_{2}$ and $\mathrm{H}_{2} \mathrm{O}_{2}$ will be discussed. Then, degradation products of the DOTA ligand will be identified and a degradation scheme will be proposed for the radiolysis of DOTA in pure water.

\section{Experimental section}

\subsection{Irradiation experiments}

Aqueous solutions of DOTA $\left(10^{-3}\right.$ to $0.1 \mathrm{~mol} \mathrm{~L}^{-1}, \mathrm{pH} 3.5$ to 4.5$)$ are alpha irradiated in PEEK (polyether etherketone) radiolysis cells including $20 \mathrm{~mL}$ of a stirred DOTA solution under $21 \mathrm{~mL}$ controlled atmosphere. A borosilicate glass disc $(\varnothing 25 \mathrm{~mm})$ with a thickness of $145 \pm$ $15 \mu \mathrm{m}\left(38.7 \mathrm{mg} \mathrm{cm}^{-2}\right)$ is used as a window to let the particle beam reach the solution. The cells are gas-tight and equipped with a system of gas sampling valves to allow analysis of the gases formed by radiolysis. The atmosphere in the cells is reconditioned air with $1 \% \mathrm{Ne}$ at initial pressure of 1.3 bar, where neon is used as an internal standard for the determination of gas concentration by gas-chromatography analysis.

The alpha particle beams $\left({ }^{4} \mathrm{He}^{2+}\right)$ are provided by the CEMHTI (Orléans, France) and ARRONAX (Nantes, France) cyclotron facilities. The ${ }^{4} \mathrm{He}^{2+}$ particles are produced by ionizing helium gas with an initial energy of $28 \mathrm{MeV}$ and $68 \mathrm{MeV}$ respectively. During its path to reach the solution, the alpha particle loses energy passing through the titanium sheet screens of the ionization chamber and the borosilicate glass window. The final energy of the particle when it arrives in the solution is calculated using SRIM-2008 software and equals $9.4 \pm 1.3 \mathrm{MeV}$ and $60.7 \pm 0.3 \mathrm{MeV}$ for CEMHTI and ARRONAX cyclotrons respectively (Ziegler et al., 2010). The helium ions are totally stopped in the solution and the values of the linear energy transfer (LET) are $95 \pm 9 \mathrm{keV} \mathrm{\mu m}^{-1}$ and $23.3 \pm 0.3 \mathrm{keV}_{\mu \mathrm{m}}^{-1}$. During all of the experiments, the current value of ${ }^{4} \mathrm{He}^{2+}$ flux, monitored by the internal Faraday cup, is calibrated to maintain $60 \mathrm{nA}$ (CEMHTI) or $30 \mathrm{nA}$ (ARRONAX) in the radiolysis cell to obtain a dose rate of around $2 \mathrm{~kJ} \mathrm{~L}^{-1} \mathrm{~min}^{-1}$.

\subsection{Dosimetry and radiolytic yields determination}

The dose rate absorbed by the irradiated solution is determined by Fricke dosimetry (Fricke et al., 1966) beforehand to DOTA radiolysis experiments. The Fricke dosimetry is a chemical method to measure directly the dose deposited in a solution. This method is based on the oxidation of $\mathrm{Fe}^{2+}$ to $\mathrm{Fe}^{3+}$ by the species produced in water radiolysis reactions. The concentration of $\mathrm{Fe}^{3+}$ formed is monitored by ex situ (CEMHTI) or in situ (ARRONAX) UV-vis spectrophotometry $\left(\lambda=304 \mathrm{~nm}, \varepsilon=2197 \mathrm{~mol}^{-1} \mathrm{~L} \mathrm{~cm}^{-1}\right)$ with an Agilent CARY-60 (CEMHTI) or CARY-4000 (ARRONAX) spectrophotometer. The ex situ absorbance measurements are performed a few minutes after the irradiation of the Fricke solution. The in situ absorbance measurements are carried out during the irradiation via two $20 \mathrm{~m}$ long fiber optics and a probe (HELLMA, optical path $10 \mathrm{~mm}$ ). This solution is actually a SuperFricke solution and is prepared by dissolving Mohr's salt $\left(\left[\mathrm{Fe}^{3+}\right]=10^{-2} \mathrm{~mol} \mathrm{~L}^{-1}\right)$ and $\mathrm{NaCl}\left(10^{-3} \mathrm{~mol} \mathrm{~L}^{-1}\right)$ in aerated aqueous 0.4 
mol L-1 $\mathrm{H}_{2} \mathrm{SO}_{4}$ solution (Hart, 1963). Sodium chloride is added to avoid any organic impurities. The dose rate received by the Fricke dosimeter is then calculated by Eq (12).

$$
\mathrm{D}_{\text {Fricke }}=\frac{1}{G\left(F e^{3+}\right) \cdot \rho_{\text {Fricke }}} \cdot \frac{d\left[\mathrm{Fe}^{3+}\right]}{d t}
$$

$\dot{\mathrm{D}}_{\text {Fricke }}\left(\mathrm{J} \mathrm{kg}^{-1} \mathrm{~min}^{-1}\right)$ is the dose rate in the Fricke dosimeter, $G\left(\mathrm{Fe}^{3+}\right)=5.6 \cdot 10^{7} \mathrm{~mol} \mathrm{~J}^{-1}$ (CEMHTI) and $11.7 \cdot 10^{7} \mathrm{~mol} \mathrm{~J}^{-1}$ (ARRONAX) are the radiolytic yields of ferric ions (Costa et al., 2012), $\rho_{\text {Fricke }}=1.024 \mathrm{~kg} \mathrm{~L}^{-1}$ is the density of the Fricke solution (Costa et al., 2012), $\left[\mathrm{Fe}^{3+}\right]$ (mol $\left.\mathrm{L}^{-1}\right)$ is the ferric ion concentration and $t(\mathrm{~min})$ is the irradiation time.

In fact, it appears more convenient to express the absorbed dose in $\mathrm{J} \mathrm{L}^{-1}$ (Eq (13)) in order to measure the radiolytic yields $\mathrm{G}(\mathrm{X})\left(\mathrm{mol} \mathrm{J}^{-1}\right)$, which represent the amount of species $\mathrm{X}$ formed by unit of energy absorbed by the solution.

$$
\dot{\mathrm{D}}=\rho \cdot \mathrm{D}_{\text {Fricke }}
$$

$\dot{\mathrm{D}}\left(\mathrm{J} \mathrm{L}^{-1} \mathrm{~min}^{-1}\right)$ is the dose rate in the solution and $\rho\left(\mathrm{kg} \mathrm{L}^{-1}\right)$ the density of the solution.

To determine the radiolytic yields of the different species studied, typically four samples with the same concentration of DOTA in pure water were irradiated with the helium ion beam for a given time (from 0 to $10 \mathrm{~min}$ ), corresponding to a precise deposited dose (from 0 to $20 \mathrm{kGy}$ ). The different species of interest are identified and quantified, starting with the gases trapped in the radiolysis cell and then followed by the chemical compounds formed in solution. The variation of the concentration of the radiolytic products versus the deposited dose is plotted to determine their radiolytic yields $\mathrm{G}(\mathrm{X})\left(\mathrm{mol} \mathrm{J}^{-1}\right) \cdot \mathrm{G}(\mathrm{X})$ is obtained from the slope at the origin of the curve, representing the dose dependency of the concentration of the products (Fig. 2) (Costagliola et al., 2016, 2017; Garaix et al., 2015). Data for determination of the radiolytic yields of formation of $\mathrm{H}_{2}, \mathrm{CO}_{2}$ and $\mathrm{H}_{2} \mathrm{O}_{2}$ presented in this paper are given in Supporting Information 1.

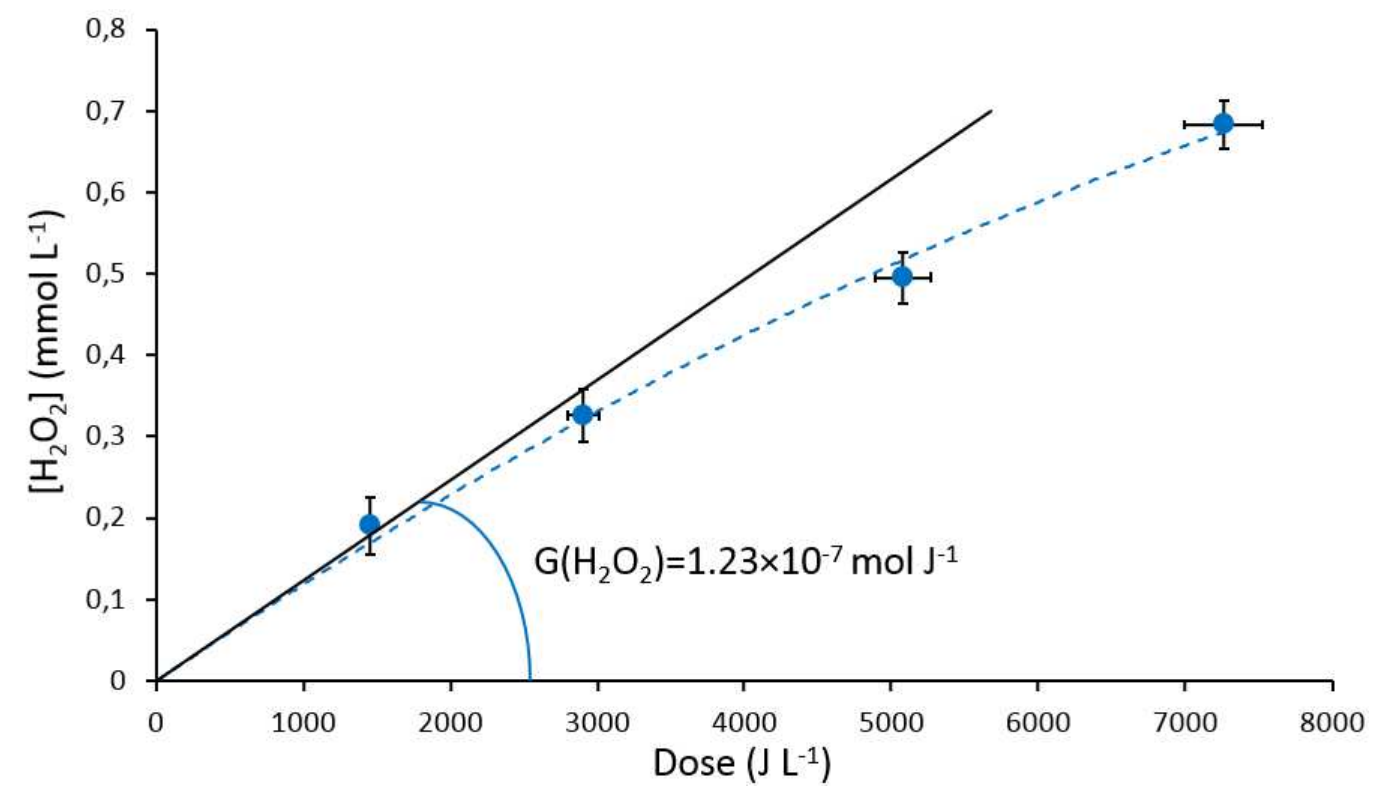


Fig. 2: Determination of the hydrogen peroxide yield from irradiated solutions of $0.1 \mathrm{~mol} \mathrm{~L}^{-1}$ DOTA in water $\left(E_{\alpha}=9.4 \mathrm{MeV}\right.$, dose rate $\left.=726 \mathrm{~J} \mathrm{~L}^{-1} \mathrm{~min}^{-1}\right)$.

The concentrations of all radiolytic products are measured by the analytical procedures described below.

The uncertainty in the radiolytic yields discussed in this article are calculated by taking into account several factors. First, the uncertainty in the determination of the analyte concentration (y-axis) depends on the uncertainty of the calibration curve of the analytical method employed, combined with the other sources of uncertainty. In particular, the position of the absorbance on the calibration curve for determination of $\mathrm{H}_{2} \mathrm{O}_{2}$ concentration, there is less uncertainty in the middle of the calibration curve than at the end. Or, for gas analysis, by taking into account the standard deviation of the surface area of gases measured by gas chromatography. Then the uncertainty of the deposited dose was evaluated to be less than 5\% (x-axis). After determination of both $\mathrm{x}$ - and $\mathrm{y}$-axis uncertainties, they are applied to the initial data to establish a maximum and a minimum radiolytic yield. The uncertainty of the radiolytic yield $(\mathrm{G}(\mathrm{X}))$ corresponds to half of the difference of the maximum and minimum yields expanded by a factor 2 for a confidence level of $95 \%$.

\subsection{Analytical procedure}

Aqueous solutions of DOTA (Chematech, Dijon, France) were prepared by dilution in deionized water at various concentrations. The commercial product was used as received (purity $100 \%$ confirmed by HPLC) with no further purification.

Gaseous species analyses were performed by micro-gas-chromatography ( $\mu \mathrm{GC}$ ) using a $\mu \mathrm{GC} 3000$ (SRA instruments, Marcy l'Etoile, France) coupled with a 5975C electronic impact mass spectrometer (Agilent, Santa Clara, CA, USA) at CEMHTI cyclotron. Four columns were used simultaneously for specific analysis of the different compounds: a $5 \AA$ molecular sieve (HP), a PoraPLOT U, a PoraPLOT Q and an OV-1. At ARRONAX an Agilent $490 \mu \mathrm{GC}$ was used with only a $5 \AA$ molecular sieve $(\mathrm{CP})$ as a column. Quantification was done using a thermal conductivity detector (TCD) on each column.

Spectrophotometric analyses of $\mathrm{H}_{2} \mathrm{O}_{2}$ were performed with an Agilent CARY-60 (CEMHTI) or CARY-4000 (ARRONAX) spectrophotometer with a slit width of $1.5 \mathrm{~nm}$, in PMMA cuvettes with an optical length of $1 \mathrm{~cm}$. The hydrogen peroxide concentration was determined by complexation with $\mathrm{Ti}^{+\mathrm{IV}}$ ions $\left(\lambda=407 \mathrm{~nm}, \varepsilon=700 \mathrm{~mol}^{-1} \mathrm{~L} \mathrm{~cm}^{-1}\right)$ (Eisenberg, 1943). The reactant was prepared by dissolving titanium (+IV) oxysulfate $\left(\mathrm{TiOSO}_{4}\right.$, Riedel de Haën) at $15 \mathrm{mmol} \mathrm{L}^{-1}$ in $0.5 \mathrm{~mol} \mathrm{~L}^{-1}$ sulfuric acid solution and used in excess. Quantification was performed using a calibration curve with standards prepared from a stock solution of $\mathrm{H}_{2} \mathrm{O}_{2}$. Also, it has been verified that the DOTA do not react with $\mathrm{H}_{2} \mathrm{O}_{2}$ by adding $10 \mathrm{mM}$ of DOTA in the standards and no influence was reported on the titration of $\mathrm{H}_{2} \mathrm{O}_{2}$.

Mass spectrometry analyses were performed with a micrOTOF-Q II (Bruker Daltonik $\mathrm{GmbH}$, Bremen, Germany) electro spray ionization (ESI) quadrupole time-of-flight (TOF) mass spectrometer. The instrument was used either in single-stage MS mode for the detection of total ions or in tandem MS mode (MS/MS) for breaking up the ions to aid in their identification (see Supporting Information 2). The data processing was performed with Compass Data Analysis 
software (Bruker Daltonik). Compass Isotope Pattern software (Bruker Daltonik) was used to calculate the isotopic pattern based on assumption and compared to the experimental data. All analyses were conducted in both positive and negative ionization mode on irradiated samples diluted at a concentration range of $10^{-4}-10^{-5} \mathrm{~mol} \mathrm{~L}^{-1}$ in $\mathrm{CH}_{3} \mathrm{CN} / \mathrm{H}_{2} \mathrm{O} 50 / 50 \mathrm{v} / \mathrm{v}$. Experimental conditions: $\mathrm{N}_{2}$ as drying and nebulizing gas, $4 \mathrm{~L} / \mathrm{min}, 0.4$ bar, $180{ }^{\circ} \mathrm{C}$, ion spray voltage of $4500 \mathrm{~V}$ (positive ion mode) or $+3500 \mathrm{~V}$ (negative ion mode), is CID $0 \mathrm{eV}$, samples injected at a rate of $180 \mu \mathrm{L} \mathrm{h}^{-1}$ with a KDS 100 Legacy syringe pump (kdScientific, Holliston, MA, USA).

${ }^{1} \mathbf{H}$ NMR analyses were performed with an Agilent DD2 $400 \mathrm{MHz}$ spectrometer equipped with a $5 \mathrm{~mm}$ OneNMR probe. Samples are placed in a coaxial insert plunged into the 5 mm OneMMR Probe filled with acetone- $\mathrm{d}_{6}$ as a deuterated reference solvent. The $\mathrm{H}_{2} \mathrm{O}{ }^{1} \mathrm{H}$ NMR signal was suppressed experimentally to enhance resolution of the DOTA signals. VnmrJ 4.2 software was used for data acquisition and NMR Notebook 2.7 software for data processing. To determine a relative percentage of DOTA degradation by NMR, the $\mathrm{H}_{2} \mathrm{O}$ in the acetone peak at $3.2 \mathrm{ppm}$ is used as an internal standard to integrate the two DOTA NMR signals at $2.3 \mathrm{ppm}$ and $2.7 \mathrm{ppm}$ before and after irradiation.

Infrared spectra were measured on a Vertex 70 FTIR Spectrometer (Bruker) with $\mathrm{KBr}$ pellets of sample solutions dried overnight at $45^{\circ} \mathrm{C}$ under argon flow. Sample solids were ground with $200 \mathrm{mg} \mathrm{KBr}$, molded into a pellet and analyzed with a pure ground $\mathrm{KBr}$ pellet as spectrum reference.

\section{Results and discussion}

\subsection{Gaseous products}

After irradiation of DOTA solutions in water, gaseous products were analyzed by microgas-chromatography. It is well known that the major gas formed by water radiolysis is molecular hydrogen $\left(\mathrm{H}_{2}\right)$ (Spinks \& Woods, 1990). Fig. 3 shows the variation of the measured hydrogen yield as a function of DOTA concentration in water. First, the obtained hydrogen yield for the radiolysis of pure water is $\mathrm{G}\left(\mathrm{H}_{2}\right)=(1.36 \pm 0.25) \times 10^{-7} \mathrm{~mol} \mathrm{~J}^{-1}$ and $(0.50 \pm 0.04) \times 10^{-7} \mathrm{~mol} \mathrm{~J}^{-1}$, respectively, for $9.4 \mathrm{MeV}$ and $60.7 \mathrm{MeV} \mathrm{E}_{\mathrm{He}}$, which are similar to the yields given in the literature (Table 1). The yields in the literature are in the range of $\mathrm{G}\left(\mathrm{H}_{2}\right)=0.64 \times 10^{-7}$ to $1.35 \times 10^{-7}$ mol J-1 for ${ }^{4} \mathrm{He}^{2+}$ particle energies of $62.2 \mathrm{MeV}$ (Crumière et al., 2013) to $6 \mathrm{MeV}$ (Essehli et al., 2011) respectively. All these values reveal the slight dependence of $\mathrm{H}_{2}$ formation with the particle LET (the LET is inversely related to the particle energy): as the LET increases $G\left(\mathrm{H}_{2}\right)$ also increases.

Table 1: $\mathrm{H}_{2}$ formation yields for the irradiation of pure water with helium ion beams.

\begin{tabular}{|c|c|c|}
\hline Energy $(\mathbf{M e V})$ & $\mathbf{G}\left(\mathbf{H}_{2}\right)\left(\times \mathbf{1 0}^{-\mathbf{7}} \mathbf{~ m o l J ~}^{-\mathbf{1}}\right)$ & Reference \\
\hline 5 & 1.2 & Pastina \& LaVerne, 2001 \\
\hline 5 & $1.35 \pm 0.13$ & Crumière et al., 2013 \\
\hline 6 & 1.35 & Essehli et al., 2011 \\
\hline 9.4 & $1.04 \pm 0.10$ & Costagliola et al., 2016 \\
\hline $\mathbf{9 . 4}$ & $\mathbf{1 . 3 6} \pm \mathbf{0 . 2 5}$ & This work \\
\hline 10.4 & 1.13 & Anderson \& Hart, 1961 \\
\hline
\end{tabular}




\begin{tabular}{|c|c|c|}
\hline 13.5 & 1.05 & Anderson \& Hart, 1961 \\
\hline 14.7 & $0.81 \pm 0.08$ & Crumière et al., 2013 \\
\hline 41.6 & 0.83 & Anderson \& Hart, 1961 \\
\hline $\mathbf{6 0 . 7}$ & $\mathbf{0 . 5 0} \pm \mathbf{0 . 0 4}$ & This work \\
\hline 62.2 & $0.64 \pm 0.07$ & Crumière et al., 2013 \\
\hline
\end{tabular}

Furthermore, for DOTA solutions in water, the hydrogen yield increases rapidly with the DOTA concentration until reaching a maximum of $G\left(\mathrm{H}_{2}\right)=(2.34 \pm 0.54) \times 10^{-7}$ mol $\mathrm{J}^{-1}$ for $10^{-2} \mathrm{~mol} \mathrm{~L}^{-1}$ DOTA concentration (Table 2), and then the hydrogen yield remains constant although the DOTA concentration continues to increase.

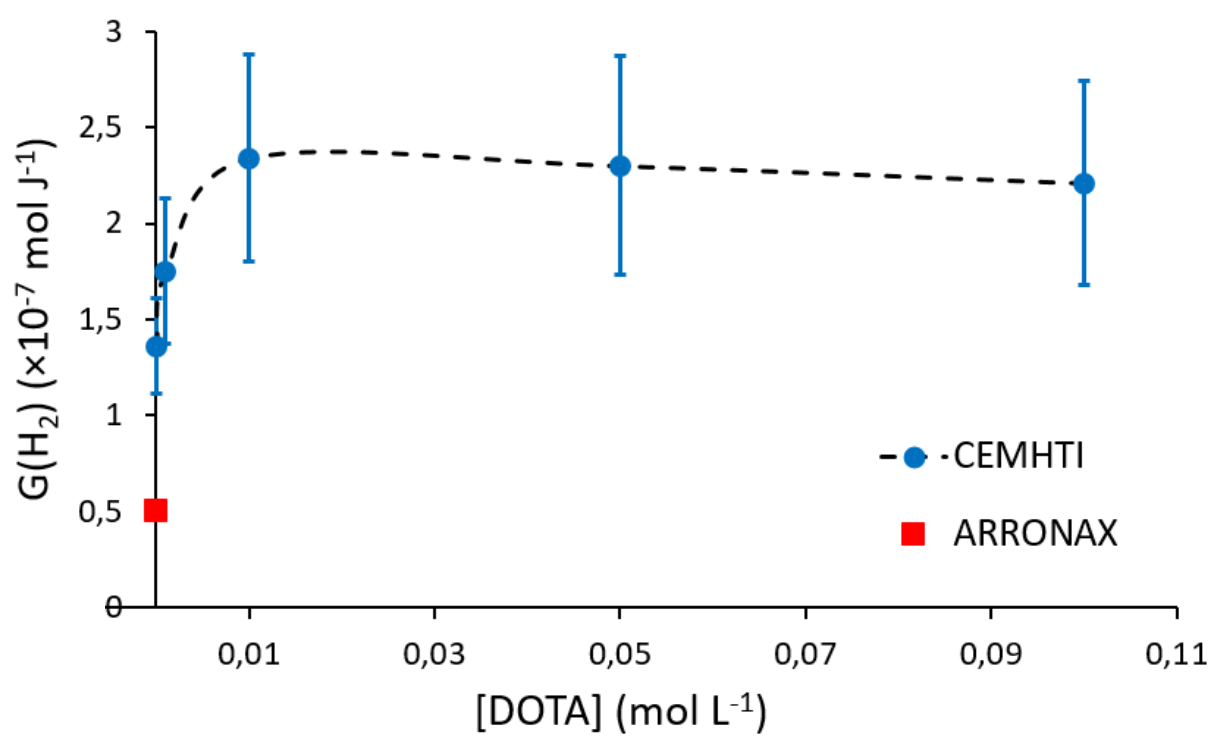

Fig. 3: Influence of DOTA concentration on the hydrogen yield for DOTA solutions in water. Samples were irradiated by CEMHTI (blue dot, $E_{\alpha}=9.4 \mathrm{MeV}$, dose rate $=1854 \mathrm{~J} \mathrm{~L}^{-1} \mathrm{~min}^{-1}$ ) and/or ARRONAX (red square, $E_{\alpha}=60.7 \mathrm{MeV}$, dose rate $=2115 \mathrm{~J} \mathrm{~L}^{-1} \mathrm{~min}^{-1}$ ) cyclotron beams.

Table 2: Hydrogen yields values for DOTA solutions in water under helium ion irradiation (CEMHTI: $E_{\alpha}=9.4 \mathrm{MeV}$ and ARRONAX: $E_{\alpha}=60.7 \mathrm{MeV}$ ).

\begin{tabular}{|c|c|c|}
\hline \multirow{2}{*}{ [DOTA] $\left(\mathbf{m o l ~ L}^{-1}\right)$} & \multicolumn{2}{|c|}{$\mathbf{G}\left(\mathbf{H}_{2}\right)\left(\times \mathbf{1 0}^{-7} \mathbf{~ m o l ~ J}^{-1}\right)$} \\
& CEMHTI $95 \mathrm{keV} \mu \mathrm{m}^{-1}$ & ARRONAX $23.3 \mathrm{keV}_{\mu \mathrm{m}}^{-1}$ \\
\hline 0 & $1.36 \pm 0.25$ & $0.50 \pm 0.04$ \\
\hline $1.0 \times 10^{-3}$ & $1.75 \pm 0.38$ & - \\
\hline $1.0 \times 10^{-2}$ & $2.34 \pm 0.54$ & - \\
\hline $5.0 \times 10^{-2}$ & $2.30 \pm 0.57$ & - \\
\hline $1.0 \times 10^{-1}$ & $2.21 \pm 0.53$ & - \\
\hline
\end{tabular}

Moreover, the radiolysis of polyaminocarboxylic acid molecules can lead to the formation of carbon dioxide $\left(\mathrm{CO}_{2}\right)$ (Toste et al., 1994). Indeed, under ionizing radiation, carboxylic acids can undergo decarboxylation by losing their carboxylic acid moiety. The DOTA molecule, which 
has four carboxylic groups, can produce a significant quantity of $\mathrm{CO}_{2}$. Fig. 4 and Table 3 show the variation of the carbon dioxide yield as a function of DOTA concentration. It is important to note that for a given LET (for example, $95 \pm 9 \mathrm{keV} \mathrm{um}^{-1}$ in the case of the CEMHTI cyclotron beam) the carbon dioxide yield $\mathrm{G}\left(\mathrm{CO}_{2}\right)$ progressively increases from $(0.34 \pm 0.05) \times 10^{-7} \mathrm{~mol} \mathrm{~J}^{-1}$ to $(1.04 \pm 0.13) \times 10^{-7} \mathrm{~mol} \mathrm{~J}^{-1}$ for $1.0 \times 10^{-3} \mathrm{~mol} \mathrm{~L}^{-1}$ to $0.1 \mathrm{~mol} \mathrm{~L}^{-1}$ of DOTA respectively. And then a plateau appears to be reached: the increase in $\mathrm{CO}_{2}$ yield is less and less important as the DOTA concentration rises. It seems that the LET influences the $\mathrm{CO}_{2}$ yield, since at ARRONAX cyclotron (with a lower LET of $\left.23.3 \pm 0.3 \mathrm{keV} \mathrm{\mu m}^{-1}\right) \mathrm{CO}_{2}$ yield reaches $(2.25 \pm 0.27) \times 10^{-7}$ mol J-1. The gamma radiolysis of $1.0 \times 10^{-3} \mathrm{~mol} \mathrm{~L}^{-1}$ EDTA, which has the same number of carboxylic acid moieties as DOTA, results in $\mathrm{G}\left(\mathrm{CO}_{2}\right)=2,4 \times 10^{-7} \mathrm{~mol} \mathrm{~J}^{-1}$.(Krapfenbauer \& Getoff, 1999) This result is slightly higher than the one with $1.0 \times 10^{-3} \mathrm{~mol} \mathrm{~L}^{-1}$ DOTA as the LET of

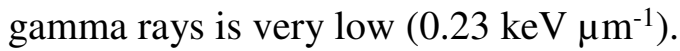

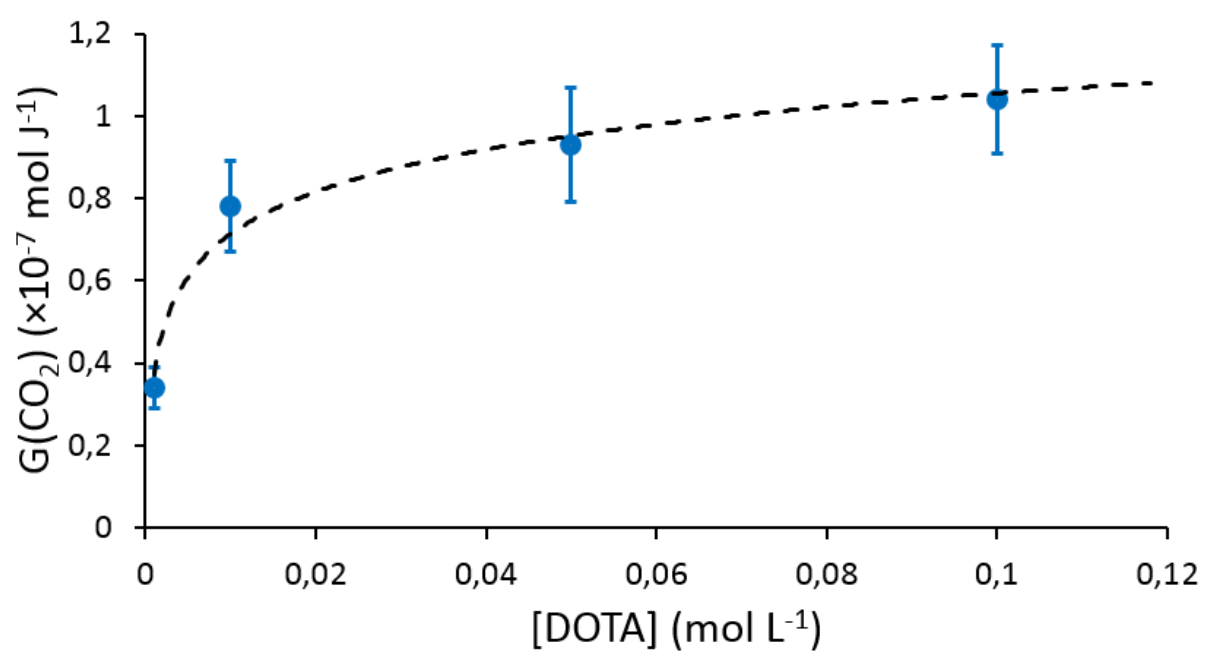

Fig. 4: Influence of DOTA concentration on the carbon dioxide yield for DOTA solutions in water. Samples were irradiated by the CEMHTI $\left(E_{\alpha}=9.4 \mathrm{MeV}\right.$, dose rate $\left.=1854 \mathrm{~J} \mathrm{~L}^{-1} \mathrm{~min}^{-1}\right)$ cyclotron beam.

Table 3: Carbon dioxide yield values for DOTA solutions in water under helium ion irradiation (CEMHTI: $E_{\alpha}=9.4 \mathrm{MeV}$ and ARRONAX: $E_{\alpha}=60.7 \mathrm{MeV}$ ).

\begin{tabular}{|c|c|c|}
\hline \multirow{2}{*}{ [DOTA] $\left(\mathbf{m o l ~ L}^{-1}\right)$} & \multicolumn{2}{|c|}{$\mathbf{G}\left(\mathbf{C O}_{2}\right)\left(\times \mathbf{1 0}^{-\mathbf{7}} \mathbf{~ m o l ~ J}^{-1}\right)$} \\
\hline $1.0 \times 10^{-3}$ & $0.34 \pm 0.05$ & - \\
\hline $1.0 \times 10^{-2}$ & $0.78 \pm 0.11$ & - \\
\hline $5.0 \times 10^{-2}$ & $0.93 \pm 0.14$ & - \\
\hline $1.0 \times 10^{-1}$ & $1.04 \pm 0.13$ & $2.25 \pm 0.27$ \\
\hline
\end{tabular}

Some other gases have been revealed by gas analysis but they were only confirmed at a deposited dose of $110 \mathrm{kGy}$. The dose range between 20 and $100 \mathrm{kGy}$ has not been studied. For doses lower than $20 \mathrm{kGy}$, a typical dose to determine radiolysis product yield, the quantity of the 
gases produced were too low to be quantified. Indeed, traces of carbon monoxide (CO), methane $\left(\mathrm{CH}_{4}\right)$, ethane $\left(\mathrm{C}_{2} \mathrm{H}_{6}\right)$, ethylene $\left(\mathrm{C}_{2} \mathrm{H}_{4}\right)$ and acetylene $\left(\mathrm{C}_{2} \mathrm{H}_{2}\right)$ have been detected.

\subsection{Hydrogen peroxide formation}

The major liquid phase product in the radiolysis of water is hydrogen peroxide (Iwamatsu et al., 2018). It has been quantified by colorimetric titration with $\mathrm{Ti}(\mathrm{IV})$. The hydrogen peroxide yields measured after radiolysis of pure water are $\mathrm{G}\left(\mathrm{H}_{2} \mathrm{O}_{2}\right)=(1.54 \pm 0.17) \times 10^{-7} \mathrm{~mol} \mathrm{~J}^{-1}$ and $(1.30 \pm$ $0.24) \times 10^{-7} \mathrm{~mol} \mathrm{~J}^{-1}$ for $9.4 \mathrm{MeV}$ and $60.7 \mathrm{MeV}$, respectively and are consistent with the yields previously measured by Garaix et al., 2015 and Costagliola et al., 2016 (Table 4). Fig. 5 shows the variation of the hydrogen peroxide yield as a function of DOTA concentration. When DOTA concentration increases, the radiolytic hydrogen peroxide yield decreases progressively until $\mathrm{G}\left(\mathrm{H}_{2} \mathrm{O}_{2}\right)=(1.23 \pm 0.45) \times 10^{-7} \mathrm{~mol} \mathrm{~J}^{-1} \quad(\mathrm{CEMHTI})$ and $\mathrm{G}\left(\mathrm{H}_{2} \mathrm{O}_{2}\right)=(0.94 \pm 0.24) \times 10^{-7} \mathrm{~mol}^{-1}$ (ARRONAX) for $0.1 \mathrm{~mol} \mathrm{~L}^{-1}$ DOTA (Table 4). The yields in the literature for the irradiation of polyaminocarboxylic acids in aqueous solutions are in the range of $\mathrm{G}\left(\mathrm{H}_{2} \mathrm{O}_{2}\right)=(2.6 \pm 0.2) \times 10^{-7} \mathrm{~mol}$ $\mathrm{J}^{-1}$ for EDTA irradiation ([EDTA] $=4.10^{-3} \mathrm{~mol} \mathrm{~L}^{-1}$, $\mathrm{pH} \mathrm{6.1)}$ and $\mathrm{G}\left(\mathrm{H}_{2} \mathrm{O}_{2}\right)=(2.5 \pm 0.1) \times 10^{-7} \mathrm{~mol} \mathrm{~J}^{-1}$ for NTA irradiation ([NTA] $=10^{-2} \mathrm{~mol} \mathrm{~L}^{-1}, \mathrm{pH} \mathrm{6.1)}$ by a $27 \mathrm{keV}$ X-ray beam (Bhattacharyya \& Kundu, 1972; Bhattacharyya \& Srisankar, 1976), and $\mathrm{G}\left(\mathrm{H}_{2} \mathrm{O}_{2}\right)=(2.6 \pm 0.3) \times 10^{-7} \mathrm{~mol} \mathrm{~J}^{-1}$ for EDTA irradiation $\left([\mathrm{EDTA}]=0.7 \mathrm{mmol} \mathrm{L}{ }^{-1}\right.$ ) by gamma radiolysis with a ${ }^{60} \mathrm{Co}$ source (Hafez et al., 1978).

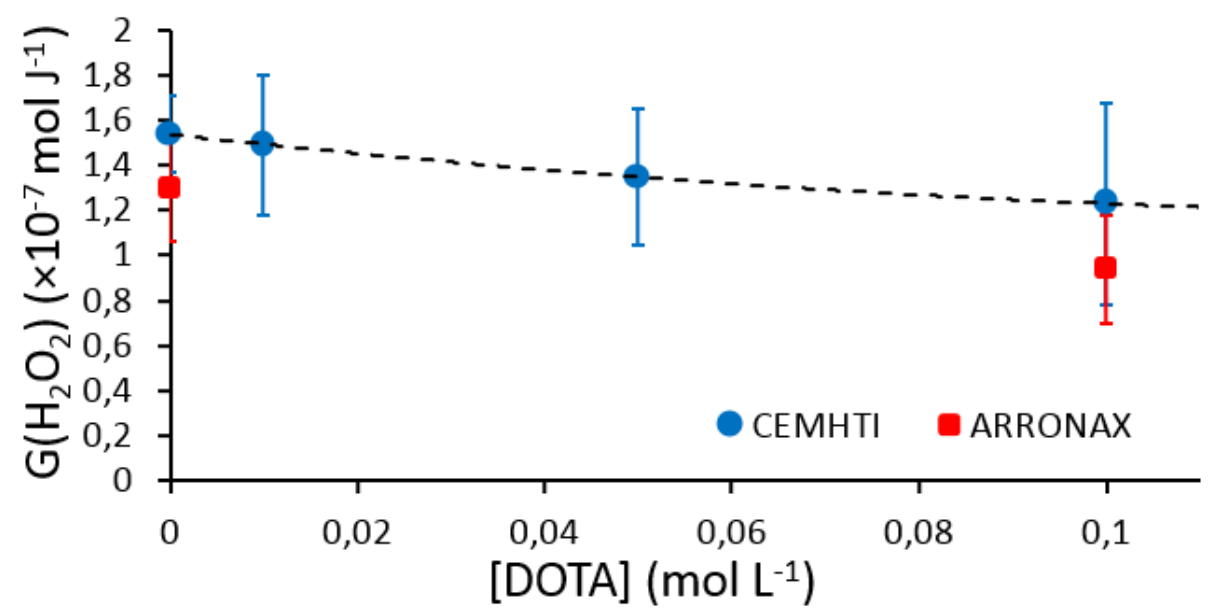

Fig. 5: Influence of DOTA concentration on the hydrogen peroxide yield for DOTA solutions in water. Samples were irradiated by CEMHTI $\left(E_{\alpha}=9.4 \mathrm{MeV}\right.$, dose rate $\left.=1854 \mathrm{~J} \mathrm{~L}^{-1} \mathrm{~min}^{-1}\right)$ and/or $\operatorname{ARRONAX}\left(E_{\alpha}=60.7 \mathrm{MeV}\right.$, dose rate $\left.=2115 \mathrm{~J} \mathrm{~L}^{-1} \mathrm{~min}^{-1}\right)$ cyclotron beams.

Table 4: Hydrogen peroxide yield values for pure water and DOTA solutions in water under helium ion irradiation (CEMHTI: $E_{\alpha}=9.4 \mathrm{MeV}$ and ARRONAX: $E_{\alpha}=60.7 \mathrm{MeV}$ ).

\begin{tabular}{|c|c|c|c|}
\hline \multirow{2}{*}{$\begin{array}{l}\text { [DOTA] } \\
\left(\mathrm{mol} \mathrm{L}^{-1}\right)\end{array}$} & \multicolumn{2}{|c|}{$\mathrm{G}\left(\mathrm{H}_{2} \mathrm{O}_{2}\right)\left(\times 10^{-7} \mathrm{~mol} \mathrm{~J}^{-1}\right)$} & \multirow{3}{*}{$\begin{array}{c}\text { References } \\
\text { Costagliola et al., } 2016\end{array}$} \\
\hline & CEMHTI $95 \mathrm{keV}_{\mu} \mathrm{m}^{-1}$ & 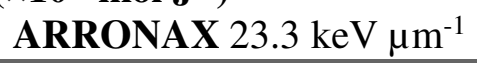 & \\
\hline $0 *$ & $1.61 \pm 0.18$ & $1.57 \pm 0.06$ & \\
\hline $0 *$ & 1.58 & 1.53 & Garaix et al., 2015 \\
\hline $0 *$ & $1.54 \pm 0.17$ & $1.30 \pm 0.24$ & This work \\
\hline $1.0 \times 10^{-2}$ & $1.49 \pm 0.31$ & - & This work \\
\hline
\end{tabular}




\begin{tabular}{|l|c|c|c|}
\hline $5.0 \times 10^{-2}$ & $1.35 \pm 0.30$ & - & This work \\
\hline $1.0 \times 10^{-1}$ & $1.23 \pm 0.45$ & $0.94 \pm 0.24$ & This work \\
\hline
\end{tabular}

* corresponds to the irradiation of pure water

\subsection{DOTA degraded solution analyses}

To be able to most accurately identify the DOTA degradation products and properly estimate a DOTA degradation rate, highly degraded DOTA solutions were needed. Hence, a $0.1 \mathrm{~mol} \mathrm{~L}^{-1}$ DOTA solution in pure water was irradiated for one hour under the helium ion beam at the CEMHTI Cyclotron, reaching a final deposited dose of $110 \mathrm{kGy}$. To gain information about the nature of the degradation products formed, IR analyses of the irradiated DOTA solution were performed.

Fig. 6 shows a comparison of IR spectra obtained for $0.1 \mathrm{~mol} \mathrm{~L}^{-1}$ DOTA solution in water before and after $110 \mathrm{kGy}$ irradiation. Upon irradiation, there is a broadening in the range 1800$1500 \mathrm{~cm}^{-1}$. This could indicate the formation of new carboxylic acids by representing a shift in the vibrational bands of the carboxylic function of the initial DOTA ligand. The other regions of the spectra are not significantly affected.

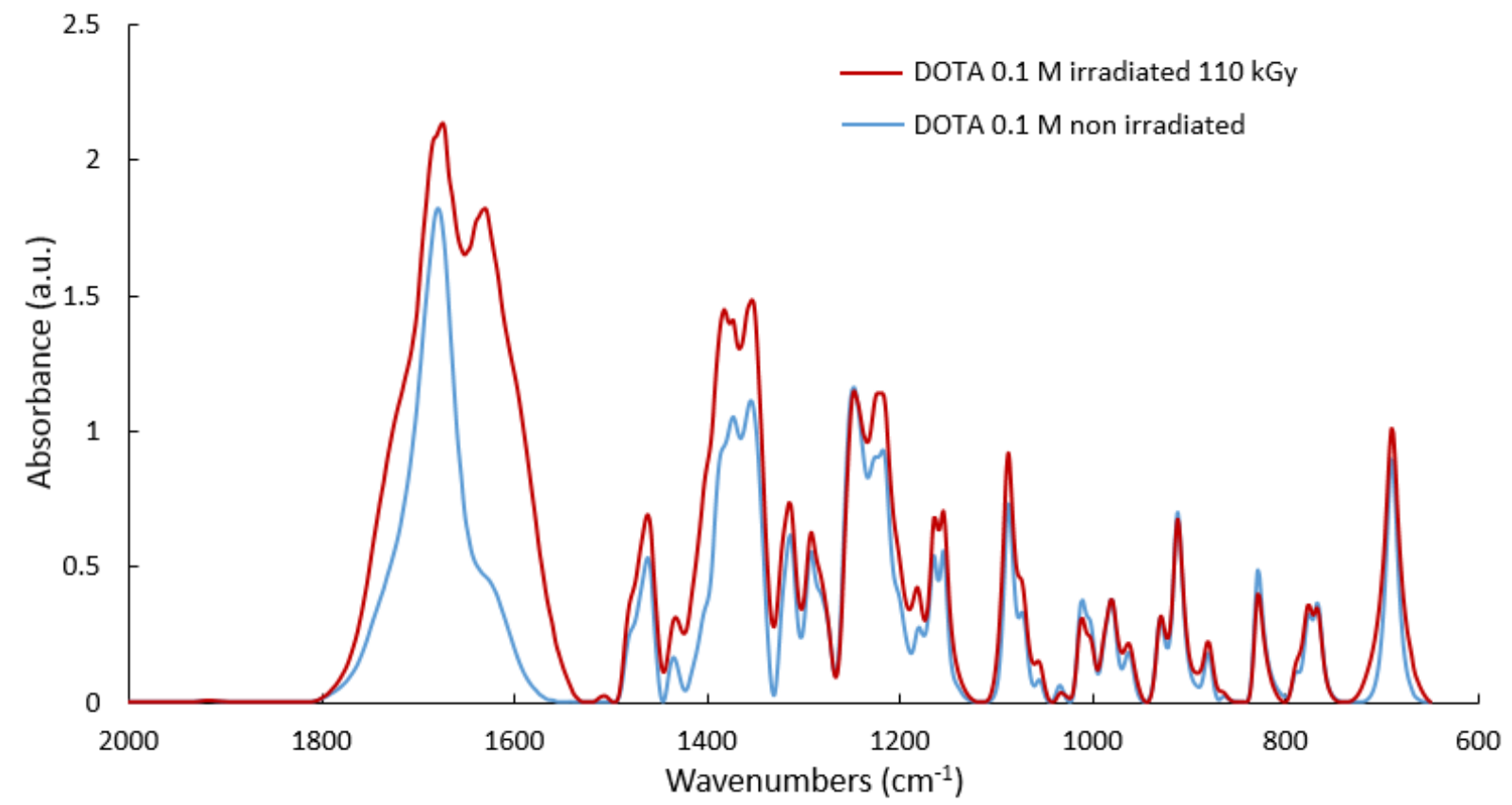

Fig. 6: Infrared spectra of $110 \mathrm{kGy}$-irradiated (red line) and non-irradiated (blue line) $0.1 \mathrm{~mol}$ $L^{-1}$ DOTA in water. Samples were dried and analyzed through $\mathrm{KBr}$ pellets (see experimental section).

Then, ${ }^{1} \mathrm{H}$ NMR spectra of a DOTA $0.1 \mathrm{~mol} \mathrm{~L}^{-1}$ in pure water solution were recorded before and after irradiation at $110 \mathrm{kGy}$ (Fig. 7). Due to its symmetry, only two different ${ }^{1} \mathrm{H}$ NMR signals were observed on the NMR spectra, at $2.3 \mathrm{ppm}$ for the $\mathbf{C H}_{2}$ from DOTA cyclen ring (4 $\mathrm{H}$ integration) and $2.7 \mathrm{ppm}$ for DOTA $\mathrm{CH}_{2} \mathrm{COOH}$ arms $(2 \mathrm{H}$ integration). After irradiation, in addition to these two intense signals, small peaks appeared between 1.6 and $3.2 \mathrm{ppm}$. These peaks could be due to the presence of degradation products of the DOTA ligand. In addition to ${ }^{1} \mathrm{H}$ 
NMR spectra, ${ }^{13} \mathrm{C}$ NMR and 2D COSY NMR spectra were also recorded, but only a few correlations between two hydrogen or two carbon atoms were observed. As these degradation products are very similar in structure and in very low concentrations, it is too difficult to identify and assign them on the spectra without a separate chromatographic technique. Nevertheless, by integration of the signals at 2.3 and $2.7 \mathrm{ppm}$, it is possible to quantify the concentration of $\mathrm{CH}_{2}$ of the cyclen ring and the concentration of $\mathrm{CH}_{2}$ of the acetate arms. This data could give us a first idea of the relative DOTA concentration in the solution. The percentage of degradation was calculated for both DOTA ${ }^{1} \mathrm{H}$ NMR signals, $\mathrm{CH}_{2}$ of the cyclen ring and $\mathrm{CH}_{2}$ of the acetate arms, at $29 \%$. Almost a third of DOTA was degraded after irradiation with a dose of $110 \mathrm{kGy}$.

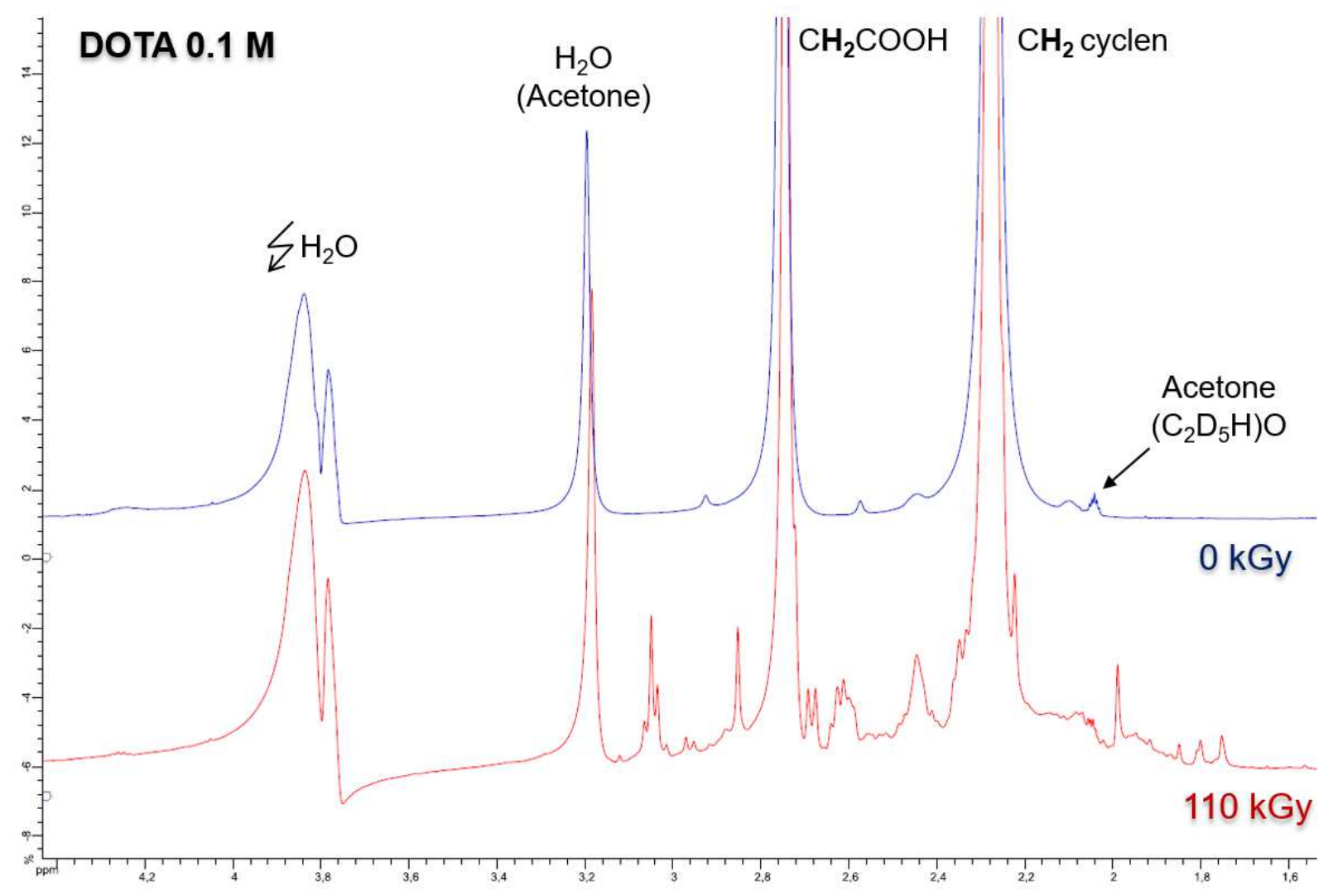

Fig. 7: ${ }^{1} \mathrm{H}$ NMR spectrum of non-irradiated (blue line) and $110 \mathrm{kGy}$-irradiated (red line) $0.1 \mathrm{~mol} \mathrm{~L}^{-1}$ DOTA in water. Acetone-d $d_{6}$ as deuterated reference solvent and with $\mathrm{H}_{2} \mathrm{O}$ signal suppressed experimentally.

In order to identify the degradation products, electrospray ionization mass spectrometry (ESI-MS), which is a highly sensitive technique for the identification of organic degradation products in relatively low concentration, was used (Drader et al., 2017, 2018). In the case of the DOTA molecule, as for polyaminocarboxylic acid, both positive and negative ionization mode can be used (Künnemeyer et al., 2008, 2009; Audras et al., 2014; Zarzana et al., 2015). In positive ionization mode, DOTA ligand is protonated leading to the formation of $\left[\mathrm{LH}_{5}\right]^{+}$, whereas in negative ionization mode DOTA ligand loses a proton, leading to $\left[\mathrm{LH}_{3}\right]^{-}$. Fig. 8 shows the ESI- 
MS spectra of the irradiated and non-irradiated DOTA solutions in both positive (A and B) and negative $(\mathrm{C}$ and $\mathrm{D})$ ionization mode. Protonated and deprotonated monomer compounds at $\mathrm{m} / \mathrm{z}=405.20\left[\mathrm{LH}_{5}\right]^{+} ; 203.08\left[\mathrm{LH}_{6}\right]^{2+} ; 403.25\left[\mathrm{LH}_{3}\right]^{-}$and $201.13\left[\mathrm{LH}_{2}\right]^{2-}$ are observed before and after irradiation in positive and negative ionization mode respectively. Also observed in the mass spectra are adducts formed with $\mathrm{K}^{+}$ions at $\mathrm{m} / \mathrm{z}=222.05\left[\mathrm{LH}_{5} \mathrm{~K}\right]^{+}$and $220.10[\mathrm{LHK}]^{2-}$. After degradation, new ions are observed in the low-molecular-weight region of the mass spectra (100$400 \mathrm{~m} / \mathrm{z}$ ). Select degradation products, corresponding to the most abundant ones, are labelled on Fig. 8 but all degradation products (DP) observed on both spectra are presented in Table 5. The formula of the degradation products has been proposed from a comparison of a simulated isotopic pattern (calculated from the assumption of the formula) with an experimental one and to be consistent with the fragmentation spectra of the corresponding ion (MS-MS) (see Supporting Information 2).

Table 5: Identification of the degradation products (DP) of DOTA

\begin{tabular}{|c|c|c|c|c|c|}
\hline DP & $\begin{array}{c}\mathbf{m} / \mathbf{z} \\
\text { positive } \\
\text { ionization }\end{array}$ & Chemical formula & $\begin{array}{c}\mathbf{m} / \mathbf{z} \\
\text { negative } \\
\text { ionization }\end{array}$ & Chemical formula & Species \\
\hline $\mathbf{A}$ & - & - & 183.15 & {$\left[\mathrm{C}_{9} \mathrm{H}_{15} \mathrm{O}_{2} \mathrm{~N}_{2}\right]^{-}$} & $\begin{array}{c}\mathrm{DOTA}-\mathrm{CO}_{2}- \\
\mathrm{NH}_{2} \mathrm{CH}_{2} \mathrm{COOH}- \\
\mathrm{CH}_{2} \mathrm{CHNH} \\
\mathrm{CH}_{2} \mathrm{COOH}\end{array}$ \\
\hline B & - & - & 186.15 & {$\left[\mathrm{C}_{8} \mathrm{H}_{16} \mathrm{O}_{2} \mathrm{~N}_{3}\right]^{-}$} & $\begin{array}{c}\text { DOTA - } 2 \\
\mathrm{CH}_{2} \mathrm{COOH}- \\
\mathrm{CH}_{2} \mathrm{CHNH} \\
\mathrm{CH}_{2} \mathrm{COOH}\end{array}$ \\
\hline & 203.08 & {$\left[\mathrm{C}_{16} \mathrm{H}_{28} \mathrm{O}_{8} \mathrm{~N}_{4}\right] \mathrm{H}_{2}{ }^{2+}$} & 201.13 & {$\left[\mathrm{C}_{16} \mathrm{H}_{26} \mathrm{O}_{8} \mathrm{~N}_{4}\right]^{2-}$} & DOTA \\
\hline C & 214.13 & {$\left[\mathrm{C}_{10} \mathrm{H}_{19} \mathrm{O}_{2} \mathrm{~N}_{3}\right] \mathrm{H}^{+}$} & 212.18 & {$\left[\mathrm{C}_{10} \mathrm{H}_{18} \mathrm{O}_{2} \mathrm{~N}_{3}\right]^{-}$} & $\begin{array}{c}\text { DOTA - } 2 \\
\mathrm{CH}_{2} \mathrm{COOH}- \\
\mathrm{NH}_{2} \mathrm{CH}_{2} \mathrm{COOH}\end{array}$ \\
\hline D & 216.11 & {$\left[\mathrm{C}_{10} \mathrm{H}_{21} \mathrm{O}_{2} \mathrm{~N}_{3}\right] \mathrm{H}^{+}$} & 214.19 & {$\left[\mathrm{C}_{10} \mathrm{H}_{20} \mathrm{O}_{2} \mathrm{~N}_{3}\right]^{-}$} & $\begin{array}{c}\mathrm{DOTA}-2 \mathrm{CO}_{2}- \\
\mathrm{CH}_{2} \mathrm{CHNH} \\
\mathrm{CH}_{2} \mathrm{COOH}\end{array}$ \\
\hline $\mathbf{E}$ & 229.17 & {$\left[\mathrm{C}_{12} \mathrm{H}_{28} \mathrm{~N}_{4}\right] \mathrm{H}^{+}$} & - & - & DOTA - $4 \mathrm{CO}_{2}$ \\
\hline $\mathbf{F}$ & - & 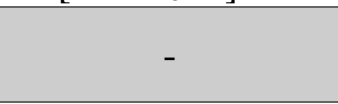 & 240.18 & {$\left[\mathrm{C}_{12} \mathrm{H}_{22} \mathrm{O}_{2} \mathrm{~N}_{3}\right]^{-}$} & $\begin{array}{l}\text { DOTA - } 2 \mathrm{CO}_{2}- \\
\mathrm{NH}_{2} \mathrm{CH}_{2} \mathrm{COOH}\end{array}$ \\
\hline $\mathbf{G}$ & - & - & 258.15 & {$\left[\mathrm{C}_{11} \mathrm{H}_{20} \mathrm{O}_{4} \mathrm{~N}_{3}\right]^{-}$} & $\begin{array}{c}\mathrm{DOTA}-\mathrm{CO}_{2} \\
-\mathrm{CH}_{2} \mathrm{CHNH} \\
\mathrm{CH}_{2} \mathrm{COOH}\end{array}$ \\
\hline $\mathbf{H}$ & 259.16 & {$\left[\mathrm{C}_{12} \mathrm{H}_{26} \mathrm{O}_{2} \mathrm{~N}_{4}\right] \mathrm{H}^{+}$} & - & - & $\begin{array}{c}\text { DOTA }-2 \mathrm{CO}_{2} \\
-\mathrm{CH}_{2} \mathrm{COOH}\end{array}$ \\
\hline $\mathbf{I}$ & - & - & 270.24 & {$\left[\mathrm{C}_{12} \mathrm{H}_{20} \mathrm{O}_{4} \mathrm{~N}_{3}\right]^{-}$} & $\begin{array}{c}\text { DOTA - } \\
\mathrm{CH}_{2} \mathrm{COOH}- \\
\mathrm{NH}_{2} \mathrm{CH}_{2} \mathrm{COOH}\end{array}$ \\
\hline $\mathbf{J}$ & 271.17 & {$\left[\mathrm{C}_{12} \mathrm{H}_{22} \mathrm{O}_{3} \mathrm{~N}_{4}\right] \mathrm{H}^{+}$} & - & - & $\begin{array}{c}\text { DOTA - } \\
\mathrm{HOCH}_{2} \mathrm{COOH}-\end{array}$ \\
\hline
\end{tabular}




\begin{tabular}{|c|c|c|c|c|c|}
\hline & & & & & $\mathrm{CH}_{2} \mathrm{COOH}$ \\
\hline $\mathbf{K}$ & 273.18 & {$\left[\mathrm{C}_{13} \mathrm{H}_{28} \mathrm{O}_{2} \mathrm{~N}_{4}\right] \mathrm{H}^{+}$} & 271.24 & {$\left[\mathrm{C}_{13} \mathrm{H}_{27} \mathrm{O}_{2} \mathrm{~N}_{4}\right]^{-}$} & DOTA $-3 \mathrm{CO}_{2}$ \\
\hline $\mathbf{L}$ & 285.15 & {$\left[\mathrm{C}_{13} \mathrm{H}_{24} \mathrm{O}_{3} \mathrm{~N}_{4}\right] \mathrm{H}^{+}$} & 283.20 & {$\left[\mathrm{C}_{13} \mathrm{H}_{23} \mathrm{O}_{3} \mathrm{~N}_{4}\right]^{-}$} & $\begin{array}{c}\mathrm{DOTA}- \\
\mathrm{HOCH}_{2} \mathrm{COOH}- \\
\mathrm{CO}_{2}\end{array}$ \\
\hline $\mathbf{M}$ & 287.18 & {$\left[\mathrm{C}_{12} \mathrm{H}_{25} \mathrm{O}_{2} \mathrm{~N}_{4} \mathrm{CHO}\right] \mathrm{H}^{+}$} & - & - & $\begin{array}{c}\text { DOTA }-3 \mathrm{CO}_{2}+ \\
\cdot \mathrm{OH}+[\mathrm{o}]^{\mathrm{a}}\end{array}$ \\
\hline $\mathbf{N}$ & 289.18 & {$\left[\mathrm{C}_{13} \mathrm{H}_{27} \mathrm{O}_{2} \mathrm{~N}_{4} \mathrm{OH}\right] \mathrm{H}^{+}$} & - & - & $\begin{array}{c}\text { DOTA }-3 \mathrm{CO}_{2}+ \\
\cdot \mathrm{OH}\end{array}$ \\
\hline $\mathbf{O}$ & 299.16 & {$\left[\mathrm{C}_{14} \mathrm{H}_{26} \mathrm{O}_{3} \mathrm{~N}_{4}\right] \mathrm{H}^{+}$} & 297.21 & {$\left[\mathrm{C}_{14} \mathrm{H}_{25} \mathrm{O}_{3} \mathrm{~N}_{4}\right]^{-}$} & $\begin{array}{c}\text { DOTA - } \\
\mathrm{HOCOOH} \mathrm{-} \mathrm{CO}_{2}\end{array}$ \\
\hline $\mathbf{P}$ & 303.19 & {$\left[\mathrm{C}_{13} \mathrm{H}_{26} \mathrm{O}_{4} \mathrm{~N}_{4}\right] \mathrm{H}^{+}$} & 301.21 & {$\left[\mathrm{C}_{13} \mathrm{H}_{25} \mathrm{O}_{4} \mathrm{~N}_{4}\right]^{-}$} & $\begin{array}{c}\text { DOTA }-\mathrm{CO}_{2}- \\
\mathrm{CH}_{2} \mathrm{COOH}\end{array}$ \\
\hline $\mathbf{Q}$ & 317.18 & {$\left[\mathrm{C}_{14} \mathrm{H}_{28} \mathrm{O}_{4} \mathrm{~N}_{4}\right] \mathrm{H}^{+}$} & 315.25 & {$\left[\mathrm{C}_{14} \mathrm{H}_{27} \mathrm{O}_{4} \mathrm{~N}_{4}\right]^{-}$} & DOTA $-2 \mathrm{CO}_{2}$ \\
\hline $\mathbf{R}$ & 329.18 & {$\left[\mathrm{C}_{14} \mathrm{H}_{24} \mathrm{O}_{5} \mathrm{~N}_{4}\right] \mathrm{H}^{+}$} & 327.23 & {$\left[\mathrm{C}_{14} \mathrm{H}_{23} \mathrm{O}_{5} \mathrm{~N}_{4}\right]^{-}$} & $\begin{array}{c}\text { DOTA - } \\
\mathrm{HOCH}_{2} \mathrm{COOH}\end{array}$ \\
\hline $\mathbf{S}$ & 331.21 & {$\left[\mathrm{C}_{13} \mathrm{H}_{25} \mathrm{O}_{4} \mathrm{~N}_{4} \mathrm{CHO}\right] \mathrm{H}^{+}$} & - & - & $\begin{array}{c}\text { DOTA - } 2 \mathrm{CO}_{2}+ \\
\cdot \mathrm{OH}+[\mathrm{o}]^{\mathrm{a}}\end{array}$ \\
\hline $\mathbf{T}$ & 333.21 & {$\left[\mathrm{C}_{14} \mathrm{H}_{25} \mathrm{O}_{4} \mathrm{~N}_{4} \mathrm{OH}\right] \mathrm{H}^{+}$} & - & - & $\begin{array}{c}\text { DOTA }-2 \mathrm{CO}_{2}+ \\
\cdot \mathrm{OH}\end{array}$ \\
\hline $\mathbf{U}$ & 343.16 & {$\left[\mathrm{C}_{15} \mathrm{H}_{26} \mathrm{O}_{5} \mathrm{~N}_{4}\right] \mathrm{H}^{+}$} & 341.21 & {$\left[\mathrm{C}_{15} \mathrm{H}_{25} \mathrm{O}_{5} \mathrm{~N}_{4}\right]^{-}$} & $\begin{array}{c}\text { DOTA - } \\
\text { HOCOOH }\end{array}$ \\
\hline $\mathbf{V}$ & 347.19 & {$\left[\mathrm{C}_{14} \mathrm{H}_{26} \mathrm{O}_{6} \mathrm{~N}_{4}\right] \mathrm{H}^{+}$} & 345.24 & {$\left[\mathrm{C}_{14} \mathrm{H}_{25} \mathrm{O}_{6} \mathrm{~N}_{4}\right]^{-}$} & $\begin{array}{l}\text { DOTA - } \\
\mathrm{CH}_{2} \mathrm{COOH}\end{array}$ \\
\hline W & 361.20 & {$\left[\mathrm{C}_{15} \mathrm{H}_{28} \mathrm{O}_{6} \mathrm{~N}_{4}\right] \mathrm{H}^{+}$} & 359.26 & {$\left[\mathrm{C}_{15} \mathrm{H}_{27} \mathrm{O}_{6} \mathrm{~N}_{4}\right]^{-}$} & DOTA - $\mathrm{CO}_{2}$ \\
\hline $\mathbf{X}$ & - & 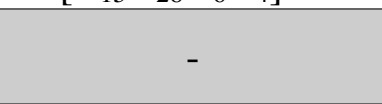 & 373.22 & {$\left[\mathrm{C}_{14} \mathrm{H}_{24} \mathrm{O}_{6} \mathrm{~N}_{4} \mathrm{CHO}\right]^{-}$} & $\begin{array}{c}\text { DOTA }-\mathrm{CO}_{2}+ \\
\cdot \mathrm{OH}+[\mathrm{o}]^{\mathrm{a}}\end{array}$ \\
\hline & 405.20 & {$\left[\mathrm{C}_{16} \mathrm{H}_{28} \mathrm{O}_{8} \mathrm{~N}_{4}\right] \mathrm{H}^{+}$} & 403.25 & {$\left[\mathrm{C}_{16} \mathrm{H}_{27} \mathrm{O}_{8} \mathrm{~N}_{4}\right]^{-}$} & DOTA \\
\hline
\end{tabular}

a [o] stands for oxidation 


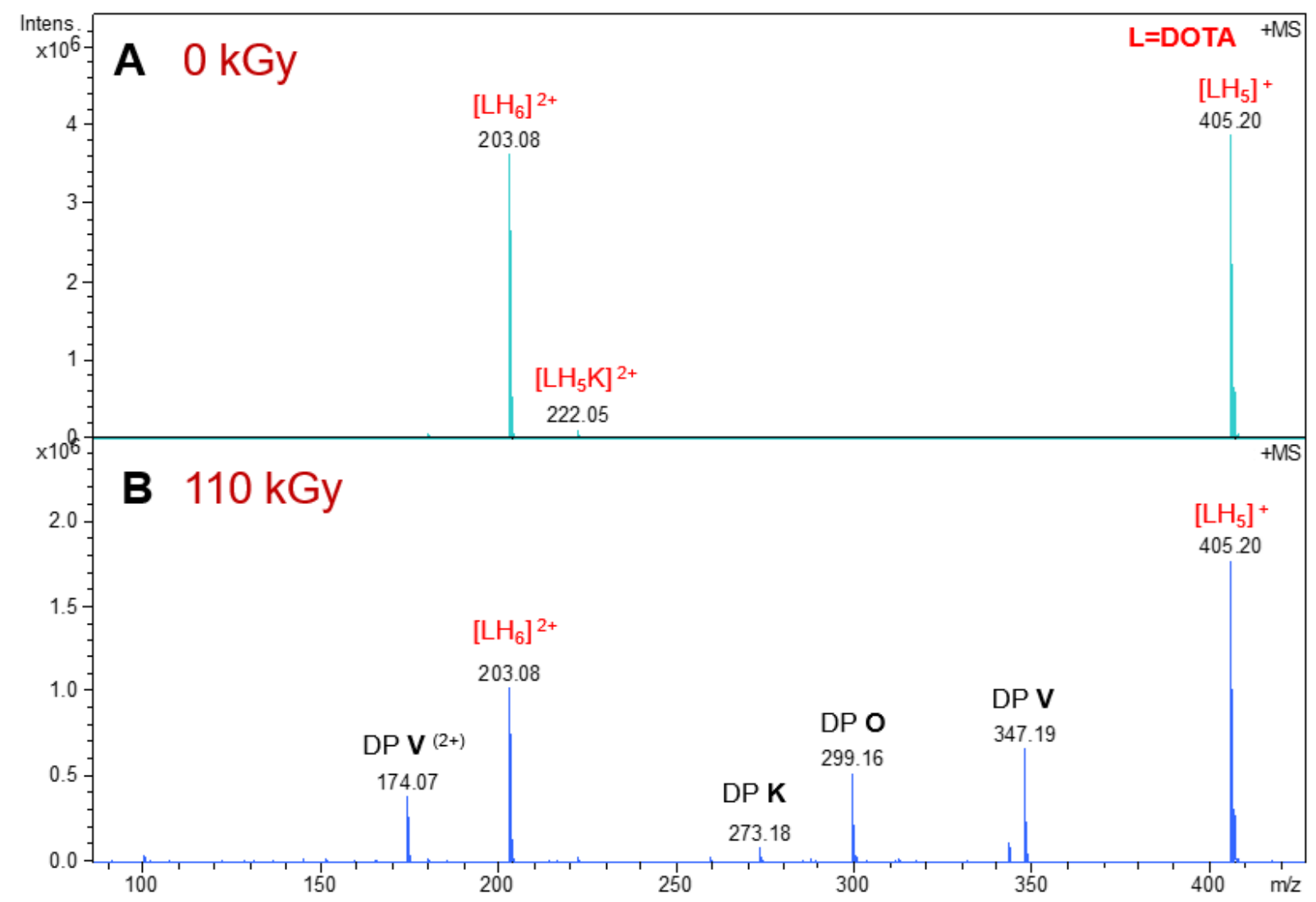




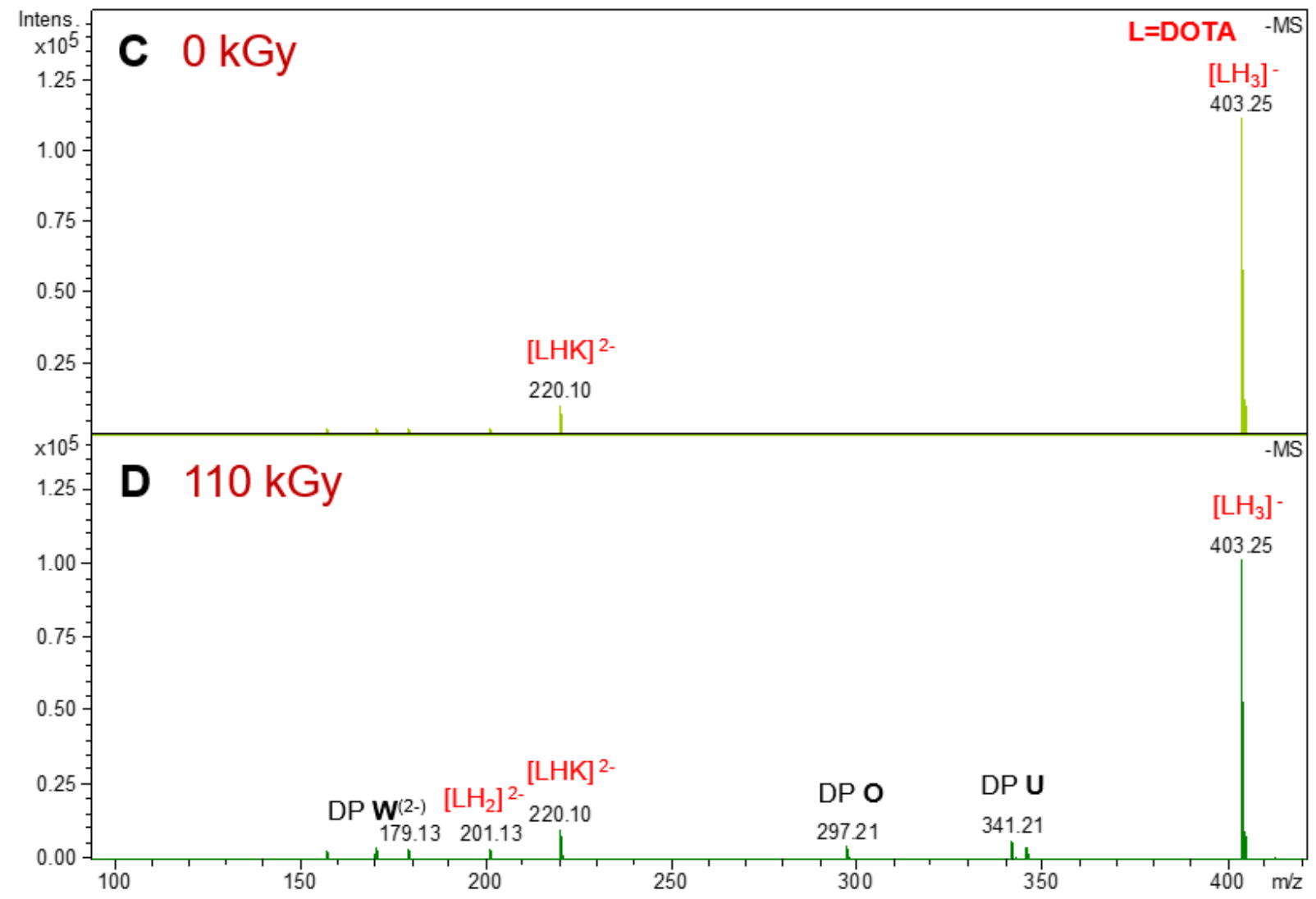

Fig. 8: ESI-MS spectra of $0.1 \mathrm{~mol} \mathrm{~L}^{-1}$ DOTA in water before ( $A$ and $\left.C\right)$ and after ( $B$ and $\left.D\right)$ alpha irradiation at $110 \mathrm{kGy}$. Positive ( $A$ and $B$ ) and negative $(C$ and $D)$ ionization mode, is $C I D O \mathrm{eV}$, dilution 1:1000 in acetonitrile/ $\mathrm{H}_{2} \mathrm{O} 50 / 50 . \mathrm{DP}=$ degradation product.

The analysis of these mass spectra suggest that for a deposited dose of $110 \mathrm{kGy}$, the DOTA molecule underwent relatively significant radiolytic degradation. The structure of the DOTA degradation products are hypothetical, as a mass spectrum does not contain structural information, but the identification of the molecular weights gives a good idea of the fragments lost by the initial DOTA molecule. The degradation products labelled Fig. 8 corresponding to the more abundant peaks are compounds $\mathbf{V}, \mathbf{U}, \mathbf{W}, \mathbf{K}$ and $\mathbf{O}$ identified in Table $\mathbf{5}$ can be formed by cleavage of the acetate arm $\mathrm{CH}_{2} \mathrm{COOH}$ (compound $\mathbf{V}$ ), condensation of two carboxylic acid groups with elimination of $\mathrm{HOCOOH}$ (carbonic acid) (compound $\mathbf{U}$ ) and decarboxylation by losing a $\mathrm{CO}_{2}$ moiety (compounds $\mathbf{W}, \mathbf{K}$ and $\mathbf{O}$ ). As these degradation products appear to be the most abundant, these cleavages are probably the most likely in the DOTA radiolysis. Fig. 9 represents a degradation route of the DOTA leading to the formation of the major compounds. 


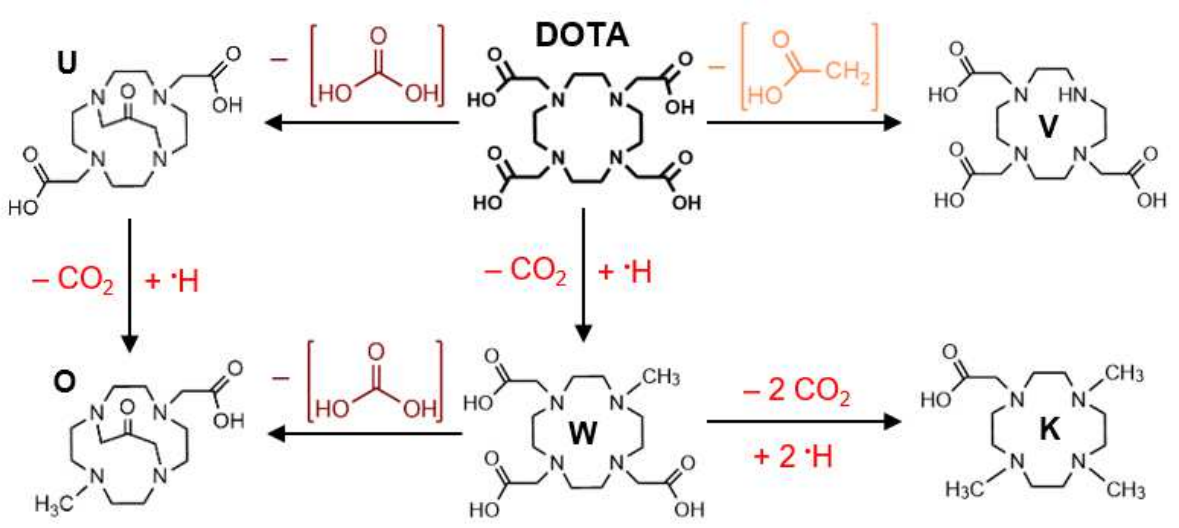

Fig. 9: General degradation pathway for DOTA radiolysis in pure water.

A deeper examination of the mass spectrum suggests further cleavages on the DOTA ligand, such as another condensation of two carboxylic acids but with elimination of $\mathrm{HOCH}_{2} \mathrm{COOH}$ (glycolic acid), or opening of the DOTA ring with elimination of $\mathrm{N}_{-} \mathrm{CH}_{2}-\mathrm{COOH}$ and $\left(\mathrm{CH}_{2}-\mathrm{CH}_{2}\right) \mathrm{N}-\mathrm{CH}_{2}-\mathrm{COOH}$. Addition of an $\mathrm{OH}$ radical followed by an oxidation of the alcohol into an aldehyde can also be observed. Based on the degradation products identified, a global degradation scheme is proposed in Fig. 10.

From the degradation products identified, it seems that the first step could be a decarboxylation of DOTA giving the six degradation products (DP) W, Q, K, and $\mathbf{E}$ (Table $\mathbf{5}$ and Fig. 10) corresponding to 4 successive losses of $\mathrm{CO}_{2}$ molecules, leaving DOTA with $\mathrm{R}-\mathrm{CH}_{3}$ ends. After decarboxylation, secondary degradation products can be formed by hydrogen abstraction with simultaneous addition of hydroxyl radical ( ${ }^{\circ} \mathrm{OH}$ ) (DP $\mathbf{T}$ and $\mathbf{N}$ ) followed by an oxidation of the alcohol function into an aldehyde moiety by losing an $\mathrm{H}_{2}$ gas molecule (DP M, $\mathbf{S}$ and $\mathbf{X}$ ). In fact, the addition of a hydroxyl radical was only observed on decarboxylated DOTA, hinting that this addition might be favored on the $\mathrm{R}_{-} \mathrm{CH}_{3}$ end of the molecule. Another facile formation route is the condensation of two carboxylic acid moieties, supposedly in opposite position to minimize steric constraint. This condensation will lead to the hypothetical loss either of a carbonic acid (- $62 \mathrm{u}$ ) for DP $\mathbf{U}$ or a glycolic acid (- $76 \mathrm{u}$ ) for DP $\mathbf{R}$. These losses can then be followed in the same case as DOTA by a decarboxylation giving DP $\mathbf{O}$ and $\mathbf{L}$, respectively. Then cleavage of a $\mathrm{CH}_{2} \mathrm{COOH}$ arm having a molecular weight 58 u lower than DOTA, either on DOTA directly with the DP $\mathbf{V}$, after $\mathrm{CO}_{2}$ losses with DP $\mathbf{P}$ and $\mathbf{H}$ or after loss of a glycolic acid group with DP J, leaving DOTA with $\mathrm{R}_{2} \mathrm{NH}$ ends (see on Fig. 10). These different fragment losses, except for the addition of ${ }^{\circ} \mathrm{OH}$ followed by an oxidation, are also proposed by Zarzana $e t$ $a l ., 2015$, for the degradation of HEDTA by gamma irradiation.

Other degradation products are observed with the cleavage of a $\mathrm{N}-\mathrm{CH}_{2}-\mathrm{COOH}$ fragment, accounting for a loss of $75 \mathrm{u}$, proposed for DP $\mathbf{C}, \mathbf{F}$ and $\mathbf{I}$. Then, with an ethylene group more, the cleavage of the fragment $\left(\mathrm{CH}_{2}-\mathrm{CH}_{2}\right) \mathrm{N}-\mathrm{CH}_{2}-\mathrm{COOH}$ is suggested for DP $\mathbf{B}, \mathbf{D}$ and $\mathbf{G}$. For the two latest fragments losses, DOTA's degradation leads to the opening of the DOTA cyclen ring by a Hofmann type elimination, resulting with hypothetically two $\mathrm{R}-\mathrm{CH}=\mathrm{CH}_{2}$ or one $\mathrm{R}-\mathrm{CH}=\mathrm{CH}_{2}$ and a R-NH ends respectively. Finally, a last radiolytic ion, only seen in negative ionization mode, as 
degradation product $\mathbf{A}$ is proposed, which can be formed either by the combination losses of $\mathrm{N}-\mathrm{CH}_{2}-\mathrm{COOH}$ and $\left(\mathrm{CH}_{2}-\mathrm{CH}_{2}\right) \mathrm{NH}-\mathrm{CH}_{2}-\mathrm{COOH}$ or the direct loss of the fragment right to $\mathbf{A}$ on Fig. 10 and not observed on the mass spectrum.

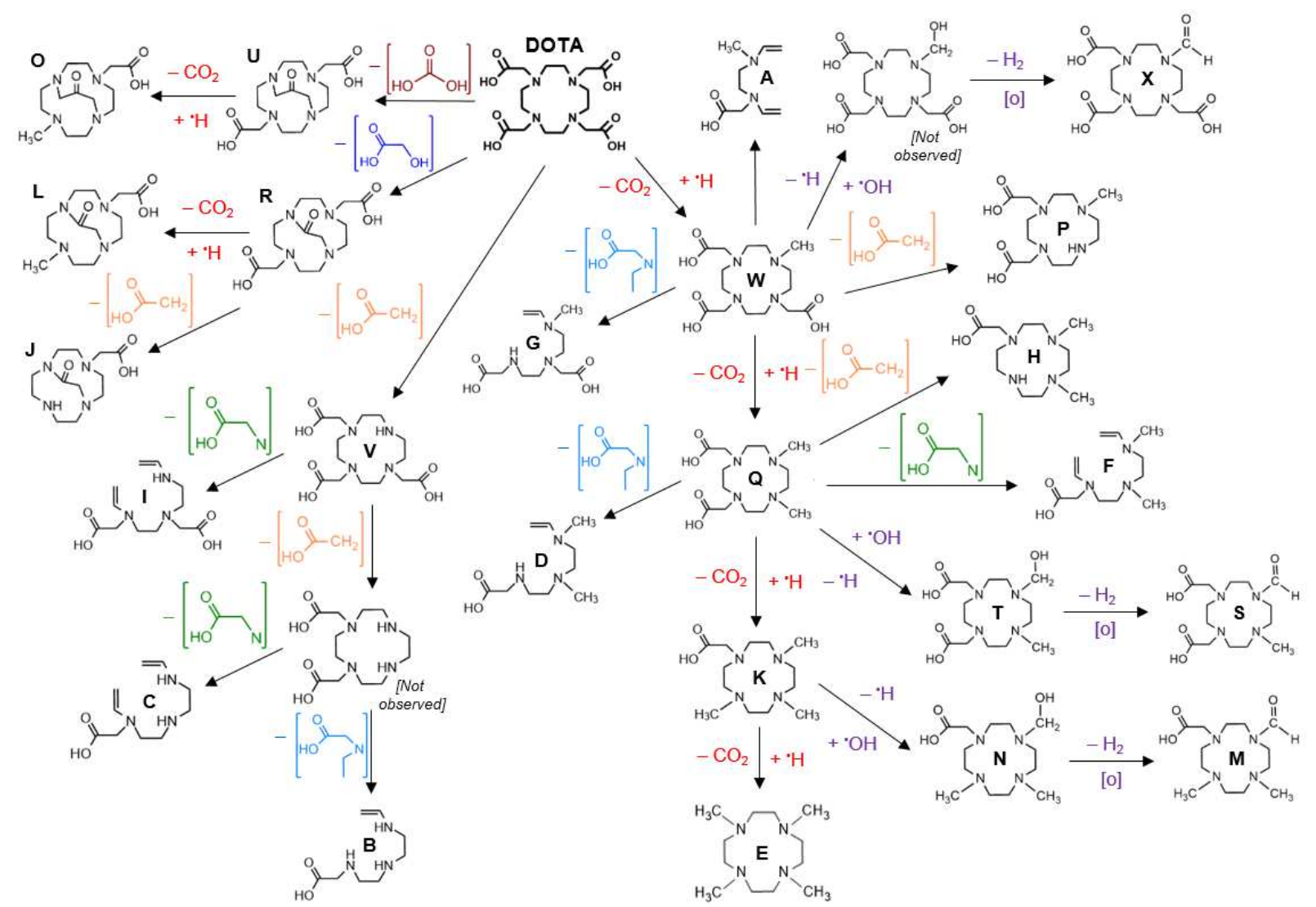

Fig. 10: Radiolytic degradation pathways for a $0.1 \mathrm{~mol} \mathrm{~L}^{-1}$ DOTA solution in pure water irradiated on the CEMHTI Cyclotron at a deposited dose of $110 \mathrm{kGy}$. Proposed structures of degradation products based on the mass of lost fragments.

The loss of all these fragments will lead to the loss of symmetry of the DOTA molecule confirmed by the infrared spectra and the NMR analysis. Before irradiation all carboxylic acids are equivalent and one $\mathrm{C}=\mathrm{O}$ peak is visible on the spectrum (Fig. 6). But after irradiation the carbonyl vibration band is broadened as carboxylic acid moieties are lost by radiolysis, breaking the equivalence of the $\mathrm{C}=\mathrm{O}$ band $\left(1800-1500 \mathrm{~cm}^{-1}\right)$. In the ${ }^{1} \mathrm{H}$ NMR study, this loss of symmetry manifests through the appearance of small new peaks in the spectrum (Fig. 7), arising from the hydrogen atoms that are now non-equivalent to those of DOTA.

\subsection{Discussion}

Irradiation of organic compounds in aqueous solutions involves chemical reactions with the products of water radiolysis. In comparison to the radiolysis of pure water, the introduction of DOTA in the solution leads to $1 /$ an increase of $\mathrm{G}\left(\mathrm{H}_{2}\right)$ from 1.36 to $2.21 \times 10^{-7} \mathrm{~mol} \mathrm{~J}^{-1}$ for 0.1 mol.L $\mathrm{L}^{-1}$ of DOTA, which corresponds to an increase of $9.2 \times 10^{-8} \mathrm{~mol}^{-\mathrm{J}^{-1}} ; 2 /$ an increase of the $\mathrm{G}\left(\mathrm{CO}_{2}\right)$ from 0 to $1.04 \times 10^{-7} \mathrm{~mol} \mathrm{~J}^{-1}$ and $3 /$ a decrease of $\mathrm{G}\left(\mathrm{H}_{2} \mathrm{O}_{2}\right)$ from 1.54 to $1.23 \times 10^{-7} \mathrm{~mol} \mathrm{~J}^{-1}$ 
which corresponds to a decrease of $3.1 \times 10^{-8}$ mol. $\mathrm{J}^{-1}$. Between the radiolysis of pure water and 0.1 mol. $\mathrm{L}^{-1}$ of DOTA, experimental error taking into account, approximately one molecule of $\mathrm{H}_{2}$ is produced per molecule of $\mathrm{CO}_{2}$.

Among the products of water radiolysis, hydrogen and hydroxyl radicals could react with the solute, typically by hydrogen abstraction (Eqs (14) and (15)) or addition through radicals recombination on the carbon chain (Eq (16)) (Mincher \& Mezyk, 2009; Spinks \& Woods, 1990).

$$
\begin{aligned}
& { }^{\circ}+\mathrm{RH}_{2} \rightarrow \mathrm{H}_{2}+{ }^{\cdot} \mathrm{RH} \\
& \cdot \mathrm{OH}+\mathrm{RH}_{2} \rightarrow \mathrm{H}_{2} \mathrm{O}+{ }^{\cdot} \mathrm{RH} \\
& \cdot \mathrm{RH}+{ }^{\cdot} \mathrm{OH} \rightarrow \mathrm{HO}-\mathrm{RH}
\end{aligned}
$$

Hydrogen radical and hydrated electron are the main precursors of molecular hydrogen formation in water radiolysis as shown in Eqs (2) to (4). But in the presence of DOTA in aqueous solution, a rapid increase in the molecular hydrogen yield is observed (Fig. 3). In order to explain this increase, it is likely that DOTA molecule reacts predominantly with the hydrogen radical by hydrogen abstraction rather than by addition, leading to this overproduction of $\mathrm{H}_{2}(\mathrm{Eq}(14))$. As the DOTA molecule is symmetrical $\left(\mathrm{C}_{4 \mathrm{v}}\right.$ symmetry group), hydrogen abstractions can occur on two positions on carbon atoms in the $\alpha$-position of a nitrogen atom (Eqs (17) and (18)) ((Sharma \& Gupta, 1984; Höbel \& von Sonntag, 1998)) stabilized by its non-paired electrons or on the carboxylic acid moiety as shown Eq (19) (Spinks \& Woods, 1990). Above a DOTA concentration of $10 \mathrm{mM}$ in aqueous solution, $\mathrm{G}\left(\mathrm{H}_{2}\right)$ no longer increases and remains constant. All hydrogen radicals formed by water radiolysis in solution have reacted with either other water radiolysis products or the DOTA molecule. However, at low LET the $\mathrm{G}\left(\mathrm{H}^{*}\right)$ in water is about $0.6 \times 10^{-7} \mathrm{~mol} \mathrm{~J}^{-1}$ (Buxton et al., 1988), which is insufficient to explain the $\mathrm{H}_{2}$ production in presence of DOTA. One assumption could be that $\mathrm{G}\left(\mathrm{H}^{*}\right)$ at $9.4 \mathrm{MeV}$ would be higher or, more likely DOTA has a sufficiently high rate coefficient for reaction with $\mathrm{H}^{*}$ to compete for $\mathrm{H}^{*}$ recombination within the lifetime of the radiation chemical track $(\mathrm{Eq}(2))$.

$$
\begin{aligned}
& \mathrm{R}_{2} \mathrm{~N}-\mathrm{CH}_{2}-\mathrm{COOH}+{ }^{\cdot} \mathrm{H} \rightarrow \mathrm{R}_{2} \mathrm{~N}-{ }^{-} \mathrm{CH}-\mathrm{COOH}+\mathrm{H}_{2} \\
& \mathrm{R}\left(\mathrm{CH}_{2} \mathrm{COOH}\right) \mathrm{N}-\mathrm{CH}_{2}-\mathrm{CH}_{2}-\mathrm{N}\left(\mathrm{CH}_{2} \mathrm{COOH}\right) \mathrm{R}+{ }^{\cdot} \mathrm{H} \rightarrow \\
& \mathrm{R}\left(\mathrm{CH}_{2} \mathrm{COOH}\right) \mathrm{N}-\mathrm{CH}_{2}-{ }^{-} \mathrm{CH}-\mathrm{N}\left(\mathrm{CH}_{2} \mathrm{COOH}\right) \mathrm{R}+\mathrm{H}_{2}
\end{aligned}
$$

$$
\mathrm{R}_{2} \mathrm{~N}-\mathrm{CH}_{2}-\mathrm{COOH}+{ }^{\cdot} \mathrm{H} \rightarrow \mathrm{R}_{2} \mathrm{~N}-\mathrm{CH}_{2}-\mathrm{COO}{ }^{\bullet}+\mathrm{H}_{2}
$$

In the case of hydrogen peroxide production, the presence of DOTA in solution has the opposite effect. The hydrogen peroxide yield is progressively decreasing with the concentration of DOTA (Fig. 5). As $\mathrm{H}_{2} \mathrm{O}_{2}$ is mainly formed by hydroxyl radical recombination (Eq (5)), this tendency is typical of a scavenging reaction (Mincher \& Mezyk, 2009). DOTA acts as a scavenger of ${ }^{\circ} \mathrm{OH}$ explaining this decline. ${ }^{\circ} \mathrm{OH}$ could play an important role in initiating DOTA degradation, indeed in the case of the radiolytic degradation of BTP in aqueous solution, calculation showed that $90 \%$ of the total degradation of the initial ligand is through reaction with ${ }^{\circ} \mathrm{OH}$ (Horne et al., 2019). ${ }^{\circ} \mathrm{OH}$ can react like ${ }^{\circ} \mathrm{H}$ by hydrogen abstraction at the same position as 
described above with the release of a water molecule. Eventually ${ }^{\circ} \mathrm{OH}$ can add to DOTA structure by recombination with the newly formed DOTA radical as shown in Eq (16). Another site of ${ }^{\circ} \mathrm{OH}$ scavenging has been revealed in Fig. 10 with degradation products $\mathbf{T}$ and $\mathbf{N}$, but the addition of the radical here is instead on decarboxylated DOTA degradation products, which is also in favor of a decline in hydrogen peroxide radiolysis yield.

Formation yields of $\mathrm{H}_{2}$ and $\mathrm{H}_{2} \mathrm{O}_{2}$ between beam energies of $9.4 \mathrm{MeV}$ at CEMHTI cyclotron and $60.7 \mathrm{MeV}$ at ARRONAX cyclotron are always slightly in favor to the lower energy beam (Table 2 and Table 4). This is the signature of the dependence of radiolysis product formation on the linear energy transfer (LET) of the beams. In fact, as the particle energy decreases, the LET increases, and more energy is deposited within the track of the particle. Then denser regions of radicals are produced leading to a higher probability of radical-radical recombination and therefore higher yields of molecular products such as $\mathrm{H}_{2}$ and $\mathrm{H}_{2} \mathrm{O}_{2}$ (LaVerne, 1996).

Moreover, carbon dioxide is produced through DOTA decarboxylation and confirmed by ESI-MS analysis with degradation products $\mathbf{W}, \mathbf{Q}, \mathbf{K}, \mathbf{E}, \mathbf{O}$ and $\mathbf{L}\left(\right.$ Fig. 10). This $\mathrm{CO}_{2}$ loss on DOTA ligand may occur according to two different pathways. First, via formation of a radical on the carboxylic acid moiety. The $\mathrm{pH}$ of the DOTA solutions used in these experiments was dependent on DOTA concentration and was between $\mathrm{pH} 3.6$ and 4.2. At this range of $\mathrm{pH}$, DOTA is present in three different forms in solution: $\mathrm{H}_{4} \mathrm{~L}, \mathrm{H}_{3} \mathrm{~L}^{-}$and $\mathrm{H}_{2} \mathrm{~L}^{2-}$ (Desreux et al., 1981). In other words, some carboxylic groups of DOTA are protonated and others deprotonated, leading to radical formation as described in Eqs (20) and (21), with $\mathrm{RCH}_{2} \mathrm{COOH}$ representing DOTA. $\mathrm{CO}_{2}$ is then formed by electron rearrangement (Eq (22)) followed by a radical recombination leading to a methyl moiety on the DOTA nitrogen (Eq (23)) as seen on Fig. 10 (Ayscough et al., 1971; Bibler, 1972).

$$
\begin{aligned}
& \mathrm{RCH}_{2} \mathrm{COOH}+{ }^{\circ} \mathrm{OH} \rightarrow \mathrm{RCH}_{2} \mathrm{COO}^{\bullet}+\mathrm{H}_{2} \mathrm{O} \\
& \mathrm{RCH}_{2} \mathrm{COO}^{-}+{ }^{\circ} \mathrm{OH} \rightarrow \mathrm{RCH}_{2} \mathrm{COO}^{\bullet}+\mathrm{HO}^{-} \\
& \mathrm{RCH}_{2} \mathrm{COO} \cdot \rightarrow \mathrm{R}^{\bullet} \mathrm{CH}_{2}+\mathrm{CO}_{2} \\
& \mathrm{R}^{\cdot} \mathrm{CH}_{2}+\cdot{ }^{\circ} \rightarrow \mathrm{RCH}_{3} \\
& \mathrm{R}^{\cdot} \mathrm{CH}_{2}+\cdot{ }^{\circ} \mathrm{OH} \rightarrow \mathrm{RCH}_{2} \mathrm{OH}
\end{aligned}
$$

Second, N. E. Bibler proposed another mechanism for decarboxylation of DTPA (diethylenetriaminepentaacetic acid) through a 6-membered ring electron rearrangement process (Bibler, 1972). This mechanism can also be adapted to the DOTA molecule and is depicted in Fig. 11. After formation of a radical on the cyclen ring of DOTA (Eq (18)), electron transfer between this radical and the hydrogen atom from the carboxylic acid nearby leads to the departure of a carbon dioxide molecule. The carbon radical created can then recombine with a hydrogen radical leading to the formation of a methyl moiety (Eq (23)) (DP W, Q, K, E, O and $\mathbf{L}$ - Fig. 10), or in one step recombine with a hydroxyl radical to form a hydroxyl adduct (Eq (24)) 
which can be further oxidized into an aldehyde function (DP T and $\mathbf{N}$ then DP $\mathbf{M}, \mathbf{S}$ and $\mathbf{X}$ - Fig. 10).

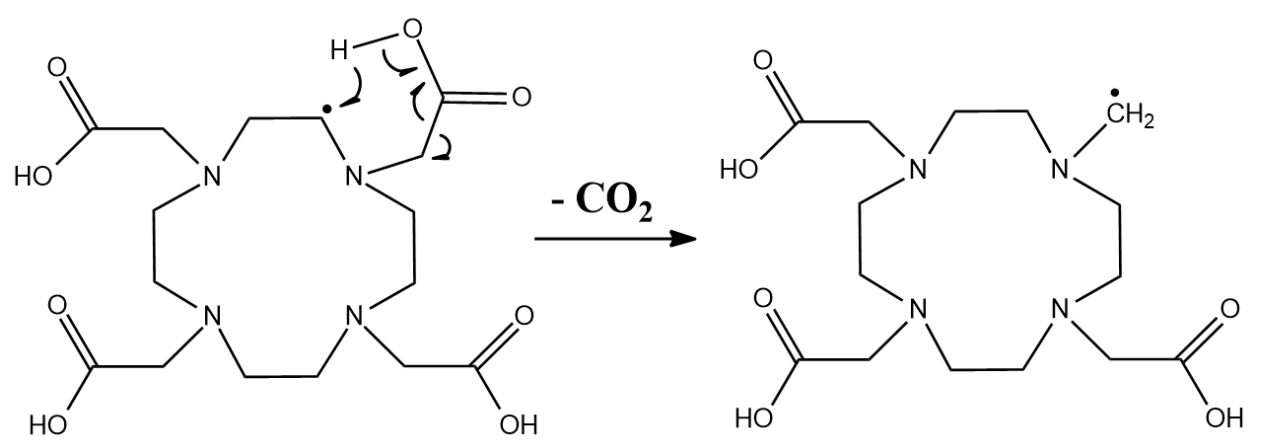

Fig. 11: Possible mechanism for the decarboxylation of DOTA.

Formation yields of $\mathrm{CO}_{2}$ are here in favor of the higher energy beam, meaning lower LET, as $\mathrm{G}\left(\mathrm{CO}_{2}\right)$ is slightly higher for irradiation at ARRONAX cyclotron. Since $\mathrm{CO}_{2}$ is initially formed by the reaction of radicals with the DOTA as shown in the mechanisms proposed above, at lower LET the distribution of the radicals produced by water radiolysis is more dispersed in the solution. The radicals are then more disposed to interact with the DOTA (Eq (18), (20) and (21)) instead of self-recombination, initiating the departure of a carbon dioxide molecule.

In addition, small quantities of carbon monoxide have also been detected after DOTA irradiation. This gas can be produced by addition of a hydrogen radical on a carboxylic acid moiety of DOTA leading to its protonation followed by successive electron transfers (Eq (25) to (28)) (Ayscough et al., 1971; Spinks \& Woods, 1990).

$$
\begin{aligned}
& \mathrm{RCH}_{2} \mathrm{COOH}+{ }^{\bullet} \mathrm{H} \rightarrow \mathrm{RCH}_{2}{ }^{\bullet} \mathrm{C}(\mathrm{OH})_{2} \\
& \mathrm{RCH}_{2} \cdot \mathrm{C}(\mathrm{OH})_{2} \rightarrow \mathrm{RCH}_{2}{ }^{\circ} \mathrm{CO}+\mathrm{H}_{2} \mathrm{O} \\
& \mathrm{RCH}_{2} \cdot \mathrm{CO} \rightarrow \mathrm{R}^{\bullet} \mathrm{CH}_{2}+\mathrm{CO} \\
& \mathrm{R}^{\cdot} \mathrm{CH}_{2}+{ }^{\circ} \mathrm{H} \rightarrow \mathrm{RCH}_{3}
\end{aligned}
$$

Finally, one major loss on the irradiated DOTA molecule identified by the ESI-MS spectrum analysis is the loss of a $-\mathrm{CH}_{2} \mathrm{COOH}$ fragment observed for degradation products $\mathbf{V}, \mathbf{P}$, $\mathbf{H}$ and $\mathbf{J}$ (Fig. 10). Many studies have evidenced this loss with other polyaminocarboxylic acids, mainly for EDTA, as the result of the reaction of the dehydrogenated radical intermediate (Eq (8)), formed by radical abstraction, with $\mathrm{O}_{2}$ (Eq (9)) and $\mathrm{H}_{2} \mathrm{O}$ (Eqs (10) and (11)), forming products such as glyoxylic acid $(\mathrm{CHOCOOH})(\mathrm{Eq}(10))$ or formaldehyde $\left(\mathrm{CH}_{2} \mathrm{O}\right)(\mathrm{Eq}(11))$ as discussed in the introduction (Bhattacharyya \& Kundu, 1972; Bhattacharyya \& Srisankar, 1976; Sharma \& Gupta, 1981, 1984; Hafez et al., 1978; Khater et al., 1987). These carbonyl compounds will further react with either the hydrated electron (Bhattacharyya \& Srisankar, 1976) or hydrogen peroxide (Höbel \& von Sonntag, 1998) and rapidly decrease in solution. In addition to these carbonyl compounds, reactions Eqs (10) and (11) lead to the formation of $\mathrm{R}_{2} \mathrm{NH}$ 
molecules (DP V, P, $\mathbf{H}$ and $\mathbf{J}$ ) which are also proposed as degradation products in Fig. $\mathbf{1 0}$ after the different losses of a $-\mathrm{CH}_{2} \mathrm{COOH}$ fragment.

\section{Conclusion}

The behavior of aqueous DOTA in solutions of pure water under helium ion irradiation have been studied through the formation yields of some radiolytic products and the identification of DOTA's degradation products. In the gas phase, the irradiation of DOTA solutions lead to an important formation of molecular hydrogen $\left(\mathrm{H}_{2}\right)$ and carbon dioxide $\left(\mathrm{CO}_{2}\right)$. Traces of carbon monoxide $(\mathrm{CO})$, methane $\left(\mathrm{CH}_{4}\right)$, ethane $\left(\mathrm{C}_{2} \mathrm{H}_{6}\right)$, ethylene $\left(\mathrm{C}_{2} \mathrm{H}_{4}\right)$ and acetylene $\left(\mathrm{C}_{2} \mathrm{H}_{2}\right)$ have also been detected. In solution, the influence of DOTA concentration on the formation of hydrogen peroxide $\left(\mathrm{H}_{2} \mathrm{O}_{2}\right)$ by water radiolysis has been studied. As DOTA concentration increases, $\mathrm{H}_{2} \mathrm{O}_{2}$ formation decreases as a consequence of $\mathrm{OH}$ scavenging by the DOTA molecule. On the contrary, the formation of molecular hydrogen $\left(\mathrm{H}_{2}\right)$ is increasing with DOTA concentration. Hydrogen radicals abstract hydrogen from the DOTA molecule, leading to the increase of $\mathrm{H}_{2}$ production. ESI-MS analysis on a highly radiolysed DOTA solution revealed that the ligand is degraded preferentially by decarboxylation, condensation of two carboxylic acid moieties with elimination of carbonic acid $\mathrm{HOCOOH}$ and cleavage of an acetate arm $\mathrm{CH}_{2}-\mathrm{COOH}$, represented on a general DOTA degradation scheme. Other degradation products are observed in lower proportion and formed by condensation of two carboxylic acids with elimination of glycolic acid $\mathrm{HOCH}_{2} \mathrm{COOH}$, recombination with a hydroxyl radical $\left({ }^{\circ} \mathrm{OH}\right)$ followed by an oxidation and cleavages of $-\mathrm{N}-\mathrm{CH}_{2}-\mathrm{COOH}$ and $-\left(\mathrm{CH}_{2}-\mathrm{CH}_{2}\right) \mathrm{N}-\mathrm{CH}_{2}-\mathrm{COOH}$ fragments leading to opening of DOTA cyclen ring. A global radiolytic degradation pathways scheme has then been suggested with all the DOTA degradation products identified. From these experimental data, degradation mechanisms for some of these decarboxylation products have been proposed. DOTA might lose $\mathrm{CO}_{2}$ moieties by different electron rearrangement processes and $-\mathrm{CH}_{2} \mathrm{COOH}$ fragments by stabilization of two DOTA radicals. NMR analyses showed that almost a third of DOTA ligand was degraded after $110 \mathrm{kGy}$ alpha irradiation dose.

In order to better appreciate the degree of stability of DOTA under alpha irradiation, an analytical method by HPLC-MS is under development for the quantification of DOTA remaining in solution after radiolysis that is more accurate than NMR studies. Moreover, the behavior of DOTA alpha radiolysis in nitric acid solutions and in presence of metallic solutes is ongoing, in order to be closer to the actinide chemical reprocessing conditions. Finally, the study of the influence of the particle LET would be interesting to understand the impact of particle energy on DOTA degradation using either other helion beam energies or directly alpha particles emitted by plutonium or americium solutions. Moreover, in order to better understand the radiolysis mechanism responsible for the DOTA degradation in aqueous solution, the reaction kinetics of the ligand with aqueous radiolysis products should be measure through time-resolved pulsed electron techniques.

\section{Acknowledgments}

The authors would like to express their gratitude to the CEMHTI, ARRONAX facility teams and the Physical and Chemical Department (DPC) of CEA Saclay especially Jean-Luc Roujou for their technical support in this study, and Vanessa Holfeltz for her help in making this 
article. This work has been supported in part by a grant from the French National Agency for Research called "Investissements d'Avenir", Equipex ArronaxPlus nANR-11-EQPX-0004.

\section{References}

Anderson, A. R. \& Hart, E. J. (1961). Radiat. Res. 14, 689.

Ansoborlo, É., Amekraz, B., Moulin, C., Moulin, V., Taran, F., Bailly, T., Burgada, R., HengéNapoli, M.-H., Jeanson, A., Den Auwer, C., Bonin, L. \& Moisy, P. (2007). Comptes Rendus Chim. 10, 1010-1019.

Audras, M., Berthon, L., Martin, N., Zorz, N. \& Moisy, Ph. (2014). J. Radioanal. Nucl. Chem. 303, 1897-1909.

Ayscough, P. B., Mach, K., Oversby, J. P. \& Roy, A. K. (1971). Trans Faraday Soc. 67, 360374.

Barr, N. F. \& Allen, A. O. (1959). J. Phys. Chem. 63, 928-931.

Bhattacharyya, S. N. \& Kundu, K. P. (1972). Int. J. Radiat. Phys. Chem. 4, 31-41.

Bhattacharyya, S. N. \& Srisankar, E. V. (1976). Int. J. Radiat. Phys. Chem. 8, 667-671.

Bibler, N. E. (1972). J. Inorg. Nucl. Chem. 34, 1417-1425.

Braley, J. C., Carter, J. C., Sinkov, S. I., Nash, K. L. \& Lumetta, G. J. (2012). J. Coord. Chem. 65, 2862-2876.

Breeman, W. A. P., de Jong, M., de Blois, E., Bernard, B. F., Konijnenberg, M. \& Krenning, E. P. (2005). Eur. J. Nucl. Med. Mol. Imaging. 32, 478-485.

Breeman, W. A. P., Jong, M., Visser, T. J., Erion, J. L. \& Krenning, E. P. (2003). Eur. J. Nucl. Med. Mol. Imaging. 30, 917-920.

Buxton, G. V., Greenstock, C. L., Helman, W. P. \& Ross, A. B. (1988). J. Phys. Chem. Ref. Data. 17, 513-886.

Byegård, J., Skarnemark, G. \& Skålberg, M. (1999). J. Radioanal. Nucl. Chem. 241, 281-290.

Chaves, S., Delgado, R. \& Da Silva, J. J. R. F. (1992). Talanta. 39, 249-254.

Choppin, G., Thakur, P. \& Mathur, J. (2006). Coord. Chem. Rev. 250, 936-947.

Clarke, E. T. \& Martell, A. E. (1991). Inorganica Chim. Acta. 190, 37-46.

Costa, C., Vandenborre, J., Crumière, F., Blain, G., Essehli, R. \& Fattahi, M. (2012). Am. J. Anal. Chem. 03, 6-11. 
Costagliola, A., Venault, L., Deroche, A., Garaix, G., Vermeulen, J., Omnee, R., Duval, F., Blain, G., Vandenborre, J., Fattahi-Vanani, M. \& Vigier, N. (2016). Radiat. Phys. Chem. 119, 186-193.

Costagliola, A., Venault, L., Deroche, A., Vermeulen, J., Duval, F., Blain, G., Vandenborre, J., Fattahi-Vanani, M. \& Vigier, N. (2017). J. Phys. Chem. A. 121, 5069-5078.

Crumière, F., Vandenborre, J., Essehli, R., Blain, G., Barbet, J. \& Fattahi, M. (2013). Radiat. Phys. Chem. 82, 74-79.

Desreux, J. F., Merciny, E. \& Loncin, M. F. (1981). Inorg. Chem. 20, 987-991.

Drader, J. A., Boubals, N., Camès, B., Guillaumont, D., Guilbaud, P., Saint-Louis, G. \& Berthon, L. (2018). Dalton Trans. 47, 251-263.

Drader, J., Saint-Louis, G., Muller, J. M., Charbonnel, M.-C., Guilbaud, P., Berthon, L., RoscioliJohnson, K. M., Zarzana, C. A., Rae, C., Groenewold, G. S., Mincher, B. J., Mezyk, S. P., McCann, K., Boyes, S. G. \& Braley, J. (2017). Solvent Extr. Ion Exch. 35, 480-495.

Eisenberg, G. (1943). Ind. Eng. Chem. Anal. Ed. 15, 327-328.

Essehli, R., Crumière, F., Blain, G., Vandenborre, J., Pottier, F., Grambow, B., Fattahi, M. \& Mostafavi, M. (2011). Int. J. Hydrog. Energy. 36, 14342-14348.

Ferrier, M. G., Radchenko, V. \& Wilbur, D. S. (2019). Radiochim. Acta. 0,.

Fricke, H., Hart, E. J. \& Attix, F. H. (1966). 167, 44-62.

Fried, J. F. \& Schubert, J. (1961). Radiat. Res. 15, 227.

Garaix, G., Venault, L., Costagliola, A., Maurin, J., Guigue, M., Omnee, R., Blain, G., Vandenborre, J., Fattahi, M., Vigier, N. \& Moisy, P. (2015). Radiat. Phys. Chem. 106, 394-403.

Goldenberg, D. M. (2002). 43, 693-713.

Gritmon, T. F., Goedken, M. P. \& Choppin, G. R. (1977). J. Inorg. Nucl. Chem. 39, 2021-2023.

Hafez, M. B., Rouhdy, H. \& Hafez, N. (1978). J. Radioanal. Chem. 43, 121-129.

Hamplová, A., Kř́̌žek, T., Kubíček, V., Bosáková, Z. \& Coufal, P. (2010). J. Sep. Sci. 33, 658663.

Hart, E. J. (1963). Chemical dosimetry at high dose rates, Argonne National Lab., USA.

Höbel, B. \& von Sonntag, C. (1998). J. Chem. Soc. Perkin Trans. 2. 509-514.

Horne, G. P., Mezyk, S. P., Moulton, N., Peller, J. R. \& Geist, A. (2019). Dalton Trans. 48, 4547-4554. 
Ishiguchi, T. \& Takahashi, S. (2010). Drugs R D. 10, 133-145.

Iwamatsu, K., Sundin, S. \& LaVerne, J. A. (2018). Radiat. Phys. Chem. 145, 207-212.

Khater, M. M., Kenawi, I. M., Atwa, A. M. \& Hafez, M. B. (1987). J. Radioanal. Nucl. Chem. 111, 17-26.

Krapfenbauer, K. \& Getoff, N. (1999). Radiat. Phys. Chem. 55, 385-393.

Künnemeyer, J., Terborg, L., Nowak, S., Brauckmann, C., Telgmann, L., Albert, A., Tokmak, F., Krämer, B. K., Günsel, A., Wiesmüller, G. A. \& Karst, U. (2009). ELECTROPHORESIS. 30, 1766-1773.

Künnemeyer, J., Terborg, L., Nowak, S., Scheffer, A., Telgmann, L., Tokmak, F., Günsel, A., Wiesmüller, G., Reichelt, S. \& Karst, U. (2008). Anal. Chem. 80, 8163-8170.

LaVerne, J. A. (1996). Nucl. Instrum. Methods Phys. Res. Sect. B Beam Interact. Mater. At. 107, 302-307.

Lumetta, G. J., Gelis, A. V., Carter, J. C., Niver, C. M. \& Smoot, M. R. (2014). Solvent Extr. Ion Exch. 32, 333-347.

Mincher, B. J. \& Mezyk, S. P. (2009). Radiochim. Acta. 97, 519-534.

Nagaishi, R. \& Kumagai, Y. (2011). Nucl. Hydrog. Prod. Handb. 6, 177-187.

Nash, K. L. (2015). Solvent Extr. Ion Exch. 33, 1-55.

Nilsson, M. \& Nash, K. L. (2009). Solvent Extr. Ion Exch. 27, 354-377.

Pastina, B. \& LaVerne, J. A. (1999). J. Phys. Chem. A. 103, 1592-1597.

Pastina, B. \& LaVerne, J. A. (2001). J. Phys. Chem. A. 105, 9316-9322.

Poinssot, C., Rostaing, C., Baron, P., Warin, D. \& Boullis, B. (2012). Procedia Chem. 7, 358366.

Poudel, D., Bertelli, L., Klumpp, J. A. \& Waters, T. L. (2017). Health Phys. 113, 30-40.

Reubi, J. C. \& Maecke, H. R. (2008). J. Nucl. Med. 49, 1735-1738.

Sharma, B. K. \& Gupta, R. (1981). Radiat. Eff. 57, 149-154.

Sharma, B. K. \& Gupta, R. (1984). Radiat. Phys. Chem. 1977. 24, 233-237.

Spinks, J. W. T. \& Woods, R. J. (1990). An introduction to radiation chemistry, New York: Wiley.

Toste, A. P. (1998). J. Radioanal. Nucl. Chem. 235, 213-219. 
Toste, A. P., Polach, K. J. \& White, T. W. (1994). Waste Manag. 14, 27-34.

Vanel, V., Berthon, L., Miguirditchian, J. M. M. \& Burdet, F. (2012). Procedia Chem. 7, 404410.

Vanel, V., Bollesteros, M.-J., Marie, C., Montuir, M., Pacary, V., Antégnard, F., Costenoble, S. \& Boyer-Deslys, V. (2016). Procedia Chem. 21, 190-197.

Wojnárovits, L., Takács, E., Dajka, K., Emmi, S. S., Russo, M. \& D’Angelantonio, M. (2004). Radiat. Phys. Chem. 69, 217-219.

Zarzana, C. A., Peterman, D. R., Groenewold, G. S., Olson, L. G., McDowell, R. G., Bauer, W. F. \& Morgan, S. J. (2015). Sep. Sci. Technol. 50, 2836-2843.

Ziegler, J. F., Ziegler, M. D. \& Biersack, J. P. (2010). Nucl. Instrum. Methods Phys. Res. Sect. B Beam Interact. Mater. At. 268, 1818-1823. 